\title{
‡USGS
}

Alteration, Slope-Classified Alteration, and Potential Lahar Inundation Maps of Volcanoes for the Advanced Spaceborne Thermal Emission and Reflection Radiometer (ASTER) Volcanoes Archive

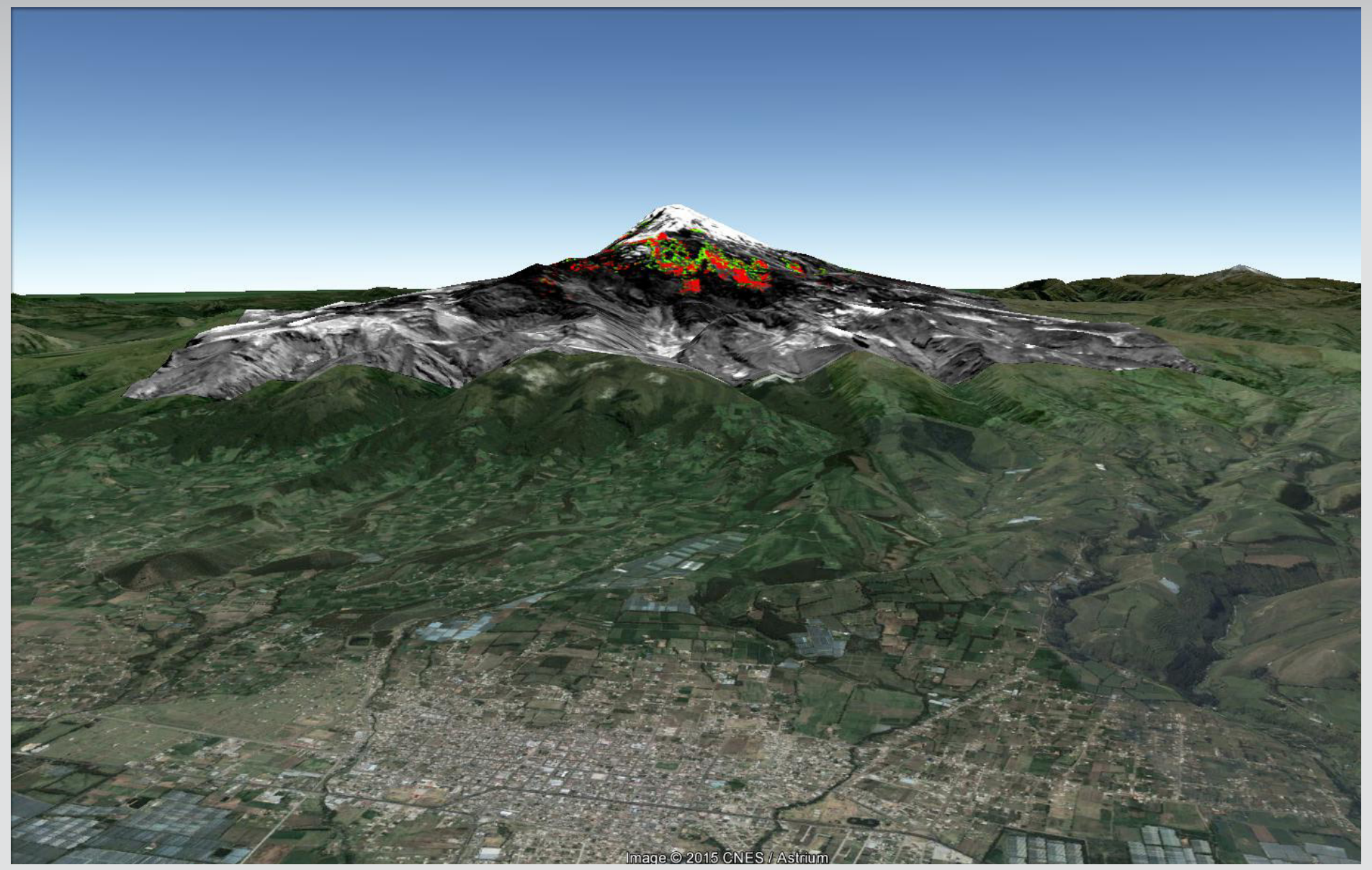

Scientific Investigations Report 2015-5035 
FRONT COVER

Google Earth perspective view of hydrothermally altered rocks and alluvium (red and green pixels) on the slopes of the volcano Nevado Cayembe, situated east of the town of Cayembe, Ecuador. 


\section{Alteration, Slope-Classified Alteration, and Potential Lahar Inundation Maps of Volcanoes for the Advanced Spaceborne Thermal Emission and Reflection Radiometer (ASTER) Volcanoes Archive}

By John C. Mars, Bernard Hubbard, David Pieri, and Justin Linick

Scientific Investigations Report 2015-5035 


\title{
U.S. Department of the Interior SALLY JEWELL, Secretary
}

\section{U.S. Geological Survey Suzette M. Kimball, Acting Director}

\author{
U.S. Geological Survey, Reston, Virginia: 2015
}

For product and ordering information: World Wide Web: http://www.usgs.gov/pubprod Telephone: 1-888-ASK-USGS

For more information on the USGS - the Federal source for science about the Earth, its natural and living resources, natural hazards, and the environment: World Wide Web: http://www.usgs.gov

Telephone: 1-888-ASK-USGS

Any use of trade, firm, or product names is for descriptive purposes only and does not imply endorsement by the

U.S. Government.

Although this report is in the public domain, permission must be secured from the individual copyright owners to reproduce any copyrighted material contained within this report.

Suggested citation:

Mars, J.C., Hubbard, B., Pieri, D., and Linick, J.L., 2015, Alteration, slope-classified alteration, and potential lahar inundation maps of volcanoes for the Advanced Spaceborne Thermal Emission and Reflection Radiometer (ASTER) Volcanoes Archive: U.S. Geological Survey Scientific Investigations Report 2015-5035, 19 p., http://www.dx.doi. org/10.3133/sir20155035. 


\section{Contents}

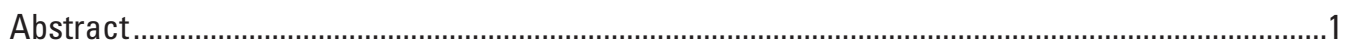

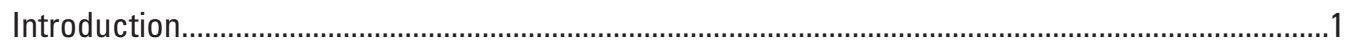

Mineral Composition and Spectral Characteristics of Volcanic Hydrothermal Deposits .................2

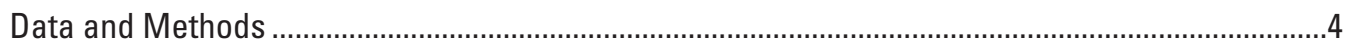

Methodology for Selection and Prioritization of Volcanoes ...................................................

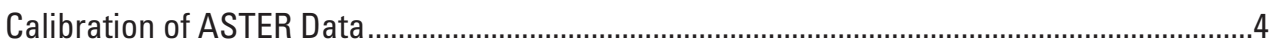

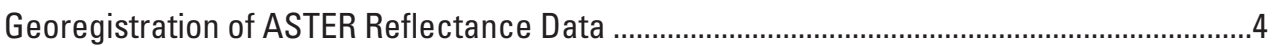

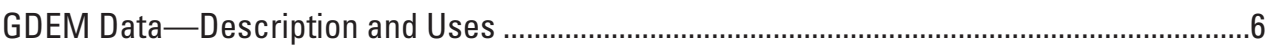

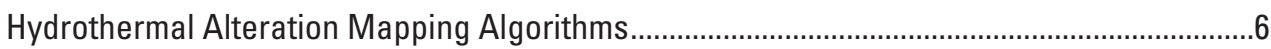

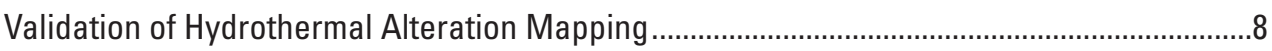

Slope-Classified Hydrothermal Alteration ................................................................................

Lahar Type Used for Modeling of Potential Inundation Areas ..................................................10

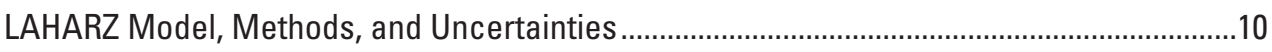

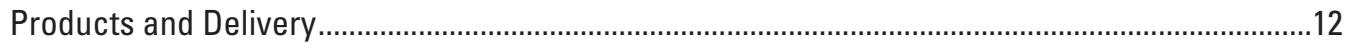

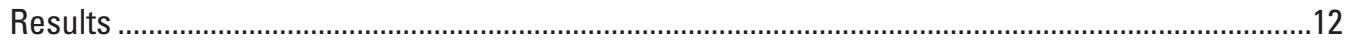

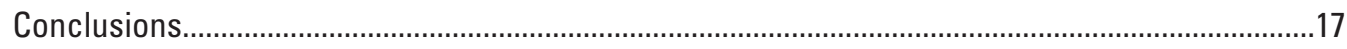

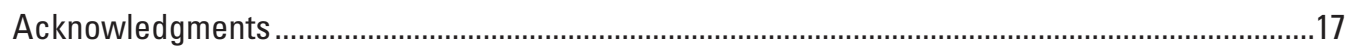

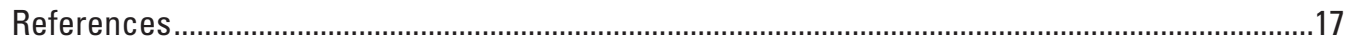

\section{Figures}

1. Comparison of two images of Mount Shasta, California, showing pixels having minerals associated with hydrothermal alteration...........................................................................

2. Plot showing reflectance of alteration minerals at wavelengths measured by ASTER ............5

3. Comparison of two maps of Pico de Orizaba, Mexico, showing minerals associated with hydrothermal alteration ..................................................................................................

4. Plots of ASTER image spectra of the lower southeastern slopes of Mount Shasta, and a sample spectrum from Pico de Orizaba compared to a composite spectrum and USGS library spectra

5. Vertical profiles showing modeled volumes of selected altered rock masses on Mount Shasta, Mount Rainier, and Mount Adams.......................................................................11

6. An ASTER hydrothermal alteration mineral map of the Iztaccíhuatl volcano showing argillic and phyllic altered rocks and jarosite-rich rocks .........................................................13

7. A shaded relief map at 30-m resolution of the Iztaccíhuatl volcano in Mexico compiled from the Global Digital Elevation Model..............................................................................14

8. A false color composite image of the Iztaccíhuatl volcano, 15-m resolution, compiled from ASTER data .

9. Example of lahar inundation map, showing Iztaccíhuatl volcano in Mexico and potential inundation along the Río Alseseca valley near the city of Puebla.. 


\section{Conversion Factors}

\begin{tabular}{llll}
\hline \multicolumn{1}{c}{ Multiply } & \multicolumn{1}{c}{ By } & \multicolumn{1}{c}{ To obtain } \\
\hline centimeter $(\mathrm{cm})$ & \multicolumn{1}{c}{ Length } \\
millimeter $(\mathrm{mm})$ & 0.3937 & inch (in.) \\
meter $(\mathrm{m})$ & 0.03937 & inch (in.) \\
kilometer $(\mathrm{km})$ & 3.281 & foot (ft) \\
meter $(\mathrm{m})$ & 0.6214 & mile (mi) \\
\hline & 1.094 & & yard (yd) \\
\hline square meter $\left(\mathrm{m}^{2}\right)$ & & Area & acre \\
square kilometer $\left(\mathrm{km}^{2}\right)$ & 0.0002471 & acre \\
square meter $\left(\mathrm{m}^{2}\right)$ & 247.1 & & square foot $\left(\mathrm{ft}^{2}\right)$ \\
\hline & 10.76 & & cubic foot $\left(\mathrm{ft}^{3}\right)$ \\
\hline cubic meter $\left(\mathrm{m}^{3}\right)$ & 35.31 & Volume & cubic yard $\left(\mathrm{yd}^{3}\right)$ \\
cubic meter $\left(\mathrm{m}^{3}\right)$ & 1.308 & & cubic mile $\left(\mathrm{mi}^{3}\right)$ \\
cubic kilometer $\left(\mathrm{km}^{3}\right)$ & 0.2399 & & \\
\hline
\end{tabular}

\section{Acronyms and Abbreviations Used}

$\begin{array}{cl}\text { ASTER } & \text { Advanced Spaceborne Thermal Emission and Reflection Radiometer } \\ \text { AVA } & \text { ASTER Volcano Archive } \\ \text { AVIRIS } & \text { Airborne Visible Infrared Imaging Spectrometer } \\ \text { DEM } & \text { Digital elevation model } \\ \text { ERSDAC } & \text { Earth Remote Sensing Data Analysis Center } \\ \text { GDEM } & \text { Global digital elevation model } \\ \text { GIS } & \text { Geographic information system } \\ \text { GPV } & \text { Global Volcanism Program database } \\ \text { IDL } & \text { Interactive data language } \\ \text { LPDAAC } & \text { Land Process Distributed Active Archive Center } \\ \text { MODIS } & \text { Moderate Resolution Imaging Spectroradiometer } \\ \text { NASA } & \text { National Aeronautics and Space Administration } \\ \text { SWIR } & \text { Short-wave near infrared } \\ \text { TIR } & \text { Thermal infrared } \\ \text { USGS } & \text { U.S. Geological Survey } \\ \text { VNIR } & \text { Visible near infrared }\end{array}$




\title{
Alteration, Slope-Classified Alteration, and Potential Lahar Inundation Maps of Volcanoes for the Advanced Spaceborne Thermal Emission and Reflection Radiometer (ASTER) Volcanoes Archive
}

\author{
By John C. Mars ${ }^{1}$, Bernard Hubbard ${ }^{1}$, David Pieri², and Justin Linick²
}

\section{Abstract}

This study identifies areas prone to lahars from hydrothermally altered volcanic edifices on a global scale, using visible and near infrared (VNIR) and short wavelength infrared (SWIR) reflectance data from the Advanced Spaceborne Thermal Emission and Reflection Radiometer (ASTER) and digital elevation data from the ASTER Global Digital Elevation Model (GDEM) dataset. This is the first study to create a global database of hydrothermally altered volcanoes showing quantitatively compiled alteration maps and potentially affected drainages, as well as drainage-specific maps illustrating modeled lahars and their potential inundation zones. We (1) identified and prioritized 720 volcanoes based on population density surrounding the volcanoes using the Smithsonian Institution Global Volcanism Program database (GVP) and LandScan ${ }^{\mathrm{TM}}$ digital population dataset; (2) validated ASTER hydrothermal alteration mapping techniques using Airborne Visible and Infrared Imaging Spectrometer (AVIRIS) and ASTER data for Mount Shasta, California, and Pico de Orizaba (Citlaltépetl), Mexico; (3) mapped and slope-classified hydrothermal alteration using ASTER VNIRSWIR reflectance data on 100 of the most densely populated volcanoes; (4) delineated drainages using ASTER GDEM data that show potential flow paths of possible lahars for the 100 mapped volcanoes; (5) produced potential alteration-related lahar inundation maps using the LAHARZ GIS code for Iztaccíhuatl, Mexico, and Mount Hood and Mount Shasta in the United States that illustrate areas likely to be affected based on DEM-derived volume estimates of hydrothermally altered rocks and the $\sim 2 \mathrm{x}$ uncertainty factor inherent within a statisticallybased lahar model; and (6) saved all image and vector data for 3D and 2D display in Google Earth ${ }^{\mathrm{TM}}$, ArcGIS ${ }^{\circledR}$ and other graphics display programs. In addition, these data are available from the ASTER Volcano Archive (AVA) for distribution (available at http://ava.jpl.nasa.gov/recent_alteration_zones.php).

Using the GVP and the LandScan ${ }^{\mathrm{TM}}$ digital population dataset, 350 of the most densely populated stratovolcanoes were assessed for study. Of the 350 volcanoes, 250 volcanoes were

\footnotetext{
${ }^{1}$ U.S. Geological Survey.
}

${ }^{2}$ National Aeronautics and Space Administration Jet Propulsion Laboratory/California Institute of Technology. not mapped due to excessive snow, ice, and (or) vegetation. Results from mapping the remaining 100 stratovolcanoes show that 87 contain slopes with hydrothermal alteration, and 49 have hydrothermally altered rocks on steep slopes situated above areas with populations $>100$ people per $\mathrm{km}^{2}$. Of these, 17 stratovolcanoes exhibit laterally extensive hydrothermal alteration on slopes $>35^{\circ}$ and cover an area $>0.25 \mathrm{~km}^{2}$, which may pose a significant possibility of generating debris flows.

This study was undertaken during 2012-2013 in cooperation with the National Aeronautics and Space Administration (NASA). Since completion of this study, a new lahar modeling program (LAHAR_pz) has been released, which may produce slightly different modeling results from the LAHARZ model used in this study. The maps and data from this study should not be used in place of existing volcano hazard maps published by local authorities. For volcanoes without hazard maps and (or) published lahar-related hazard studies, this work will provide a starting point from which more accurate hazard maps can be produced. This is the first dataset to provide digital maps of altered volcanoes and adjacent watersheds that can be used for assessing volcanic hazards, hydrothermal alteration, and other volcanic processes in future studies.

\section{Introduction}

This study was undertaken during 2012-2013 in cooperation with the National Aeronautics and Space Administration (NASA). In this study we identify hydrothermally altered volcanic edifices and vulnerable areas downstream by (1) mapping hydrothermal alteration on volcanoes using data from the Advanced Spaceborne Thermal Emission and Reflection Radiometer (ASTER), (2) highlighting watersheds that are prone to lahars using ASTER Global Digital Elevation Model (GDEM) data, and (3) modeling potential lahar inundation areas using LAHARZ, an ArcGIS ${ }^{\circledR}$ flow-fill modeling program (Iverson and others, 1998; Schilling, 1998). Many of the altered and potentially hazardous areas are difficult to study on the ground because of the inaccessibility of the terrain. Remote sensing mitigates this problem and helps to identify areas of study that might be otherwise missed by conventional field-based mapping missions. 
Lahar is an Indonesian term that describes a fast-moving, hot or cold mixture of water and rock debris that flows down volcanic slopes or river valleys (Vallance, 2000). Lahars can kill large numbers of people, sometimes without precursors such as seismicity, edifice deformation, or volcanism (Opfergelt and others, 2006; Scott and others, 2005; Vallance, 2000). For example, in 1995, excessive rain from Hurricane Mitch triggered a lahar on the flank Casita volcano, Nicaragua, that killed approximately 2,500 people in the towns of El Porvenir and Rolando Rodriguez (Scott and others, 2005).

Depending on the sediment-water mixture, lahars can be further classified as debris flows, transitional flows, or hyperconcentrated flows (Vallance, 2000). Debris flows are sediment-water mixtures containing between 50 and 75 percent sediment by volume relative to water, and most typically exhibit non-Newtonian flow properties. Hyperconcentrated flows are sediment-water mixtures containing between 20 and 60 percent sediment by volume relative to water (Beverage and Culbertson, 1964; Pierson and Costa, 1987; Vallance, 2000). Transitional flows between hyperconcentrated and debris flows occur within the 50-60 percent gradational boundary (Vallance, 2000).

Lahars have a variety of triggering mechanisms and modes of emplacement (Vallance, 2000). The large volumes of water that generate lahars on volcanoes may be derived from storms that saturate the ground, from accumulation of water in crater lakes, and (or) from melting of glaciers by volcanic eruptions (Vallance, 2000, 2005). Volcanoes are prone to landslides, due to their inherently weak rock structure. Some volcanic edifices are further weakened by hydrothermal systems that alter the volcanic rock to clay-rich minerals. The interaction of excessive water and weak or unconsolidated rock debris can produce landslides that become lahars that scour slopes and river valleys (Vallance, 2000, 2005). For example, some avalanche lahars are triggered by an avalanche of unaltered clastic rock that temporarily blocks drainages; lahars are generated later when the dams break and flood the valley below. Other avalanche lahars may be formed from the mixing of pyroclastic deposits on steep slopes with glacial melt water or water from large rain storms (Vallance, 2000, 2005).

This study focuses on mapping hydrothermally altered rocks on steep slopes that can generate clay-rich, edifice- or flank-collapse-induced lahars (rather than clay-poor lahars emplaced by other mechanisms; Vallance, 2000, 2005). Hydrothermal alteration occurs when heated groundwater interacts with volcanic rocks and produces argillic and phyllic minerals such as alunite, kaolinite, smectite, and sericite, which has been shown to weaken volcanic edifices and increase the potential for triggering lahars (Crandell, 1971; Scott and others, 1995). For example, although rain was the primary trigger of the Casita volcano lahar, the volcanic sector at the origin of the collapse consisted primarily of hydrothermally altered, smectite-rich, volcanic rock (Devoli and others, 2009; Opfergelt and others, 2006; Scott and others, 2005, Vallance and others, 2004). Many hydrothermally altered volcanoes, such as Mount Rainier, have produced larger clay-rich, edifice-collapse lahars (Scott and others, 1995; Cameron and Pringle, 1986). For example, the towns of Enumclaw and Buckley, Washington, are built on top of hydrothermally altered deposits up to 70 feet thick from the ancient Osceola mudflow lahar that originated from Mount Rainier about 5,600 years ago (Crandall and Waldron, 1956; Vallance and Scott, 1997). The Osceola mudflow occurred when a large hydrothermally altered section of the volcano collapsed. The lahar deposit extends more than 70 kilometers from Mount Rainier to Puget Sound near Tacoma, Washington, an area with a population of approximately 200,000 (Bhaduri and others, 2007; Scott and others, 1995).

Hydrothermally altered rocks have been successfully mapped on stratovolcanoes using Visible Near Infrared (VNIR) and Short-Wave Infrared (SWIR) data from the Airborne Visible/Infrared Imaging Spectrometer (AVIRIS) and Hyperion (fig. 1; Crowley and Zimbelman, 1997; Crowley and others, 2003). In addition, Crowley and others (2003) have compiled slope-classified alteration maps from Digital Elevation Maps (DEM), AVIRIS, and Hyperion data that illustrate hazardous source areas based on volumes of altered rocks and degrees of slope on which these rocks are exposed (Crowley and others, 2003). These maps illustrate where laterally extensive hydrothermally altered rocks are located on steeply sloping volcanic edifices, suggesting a high potential for lahars and highlighting the direction and drainage pathways of potential flows.

ASTER measures reflected radiation in 3 bands in the 0.52 to $0.86-\mu \mathrm{m}$ wavelength region (VNIR); 6 bands in the 1.6 to $2.43-\mu \mathrm{m}$ wavelength region (SWIR); and 5 bands of emitted radiation in the 8.125 to $11.65-\mu \mathrm{m}$ wavelength region (TIR, Thermal Infrared) with 15-m, 30-m, and 90-m resolution, respectively (Fujisada, 1995). ASTER also has a backwardlooking VNIR telescope with 15-m resolution. Thus, stereoscopic VNIR images can be acquired at 15-m resolution and have been used to produce an ASTER Global Digital Elevation Map (ASTER GDEM). ASTER has a swath width of $60 \mathrm{~km}$ and can be pointed off nadir up to $+24^{\circ}$ for the VNIR and $+8.5^{\circ}$ for the SWIR and TIR (Fujisada, 1995).

\section{Mineral Composition and Spectral Characteristics of Volcanic Hydrothermal Deposits}

Previous studies have identified argillic and phyllic hydrothermal alteration that result in clay-dominated lithofacies associated with volcanic edifices (Crowley and Zimbelman, 1997; John and others, 2008; Zimbelman, 1996; Zimbelman and others, 2005). Both types of alteration are interpreted to result from prolonged circulation of hydrothermal fluids, which results in mineral replacements and fracture filling that alters the host rock into clays (John and others, 2008; Zimbelman, 1996; Zimbelman and others, 2005). Argillic hydrothermal alteration on volcanic edifices primarily consists of alunite-, 
$\boldsymbol{A}$

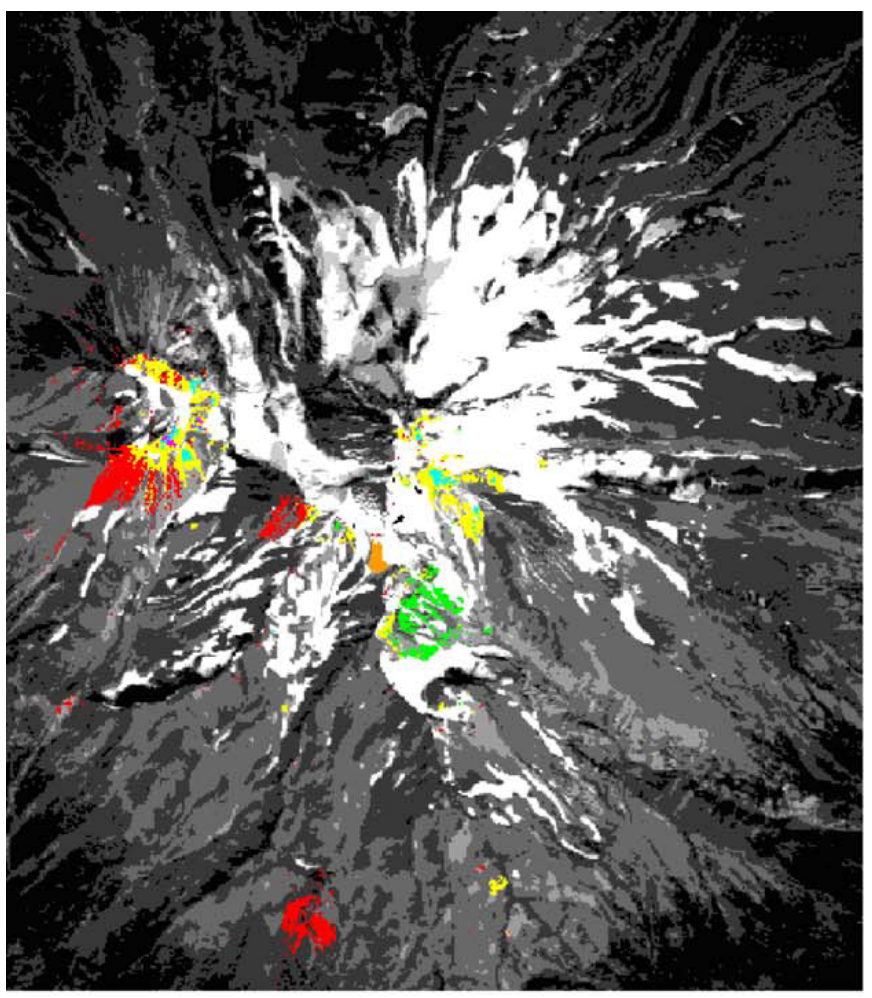

\section{AVIRIS mineral map:}

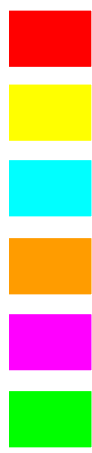

Fe-oxide

Kaolinite

Alunite \pm kaolinite \pm gypsum

Red banks oxide

Hydrous silica

Amphibole-rich flows

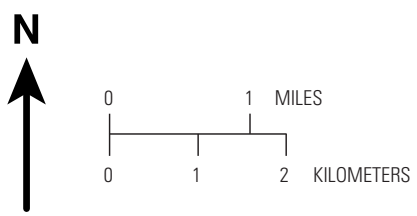

B

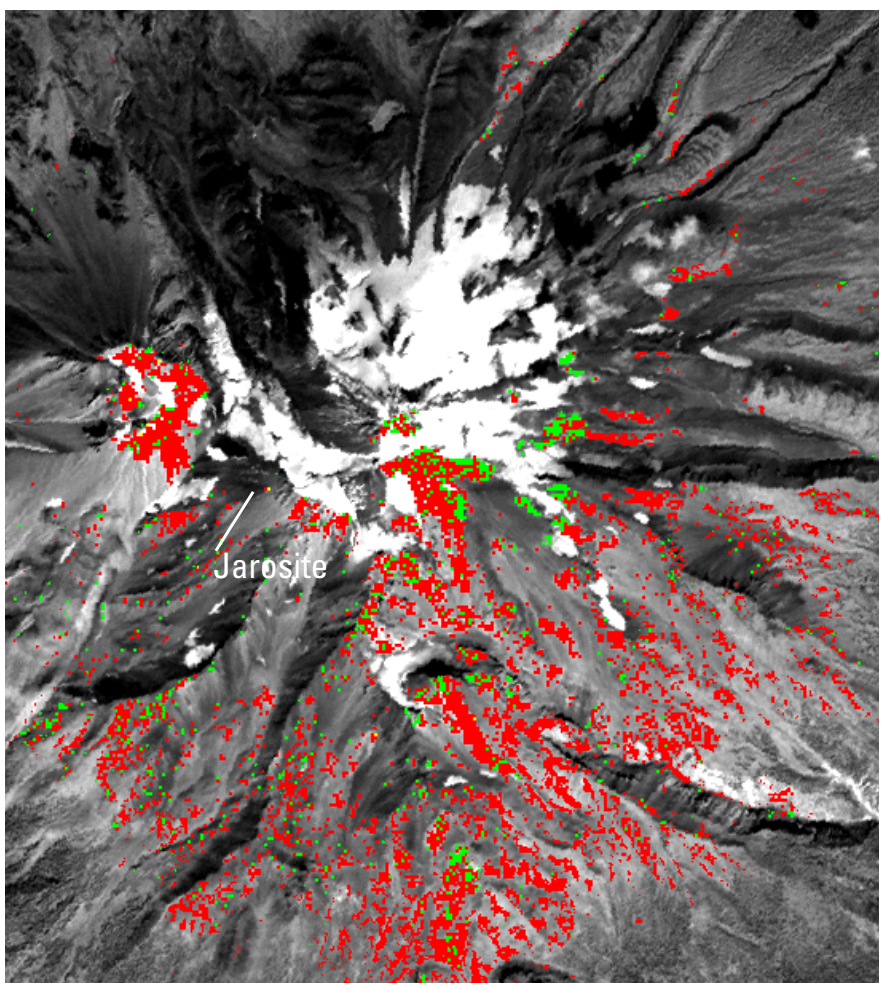

ASTER mineral map:

Argillic-altered rocks (alunite, kaolinite)

Phyllic-altered rocks (muscovite, smectite)

Jarosite-rich rocks

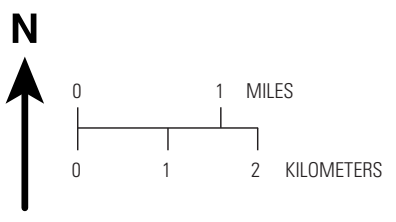

Figure 1. Comparison of two images of Mount Shasta, California, showing pixels having minerals associated with hydrothermal alteration, made using spectral data from AVIRIS (Airborne Visible/Infrared Imaging Spectrometer) and ASTER (Advanced Spaceborne Thermal Emission and Reflection Radiometer). A, Alteration mineral map of Mount Shasta, California, derived from AVIRIS data. Argillic minerals include kaolinite and alunite (blue and yellow pixels). B, Alteration mineral map of Mount Shasta, California, derived from ASTER data. 
kaolinite-, and smectite-rich volcanic rocks (John and others, 2008). Phyllic hydrothermal alteration consists of sericite (fine-grained muscovite), chlorite, and quartz-rich porphyrystyle breccias, veins, and stockworks (Zimbelman, 1996). The phyllic alteration mineral assemblage typically represents higher temperatures and pressures and is therefore not often exposed at the surface of a volcano, but may be present on deeply eroded volcanic edifices (John and others, 2010; Mars, 2014). The mineral jarosite is a common weathering product of pyrite-rich, acid-generating, hydrothermally altered rocks on volcanic slopes and is another indicator of hydrothermal alteration in volcanic settings (Hubbard, 2001; Zimbelman and others, 2005). Thus, hydrothermal alteration maps for this study include argillic hydrothermally altered rocks that contain alunite, kaolinite, and smectite, phyllic hydrothermally altered rocks that contain sericite (illite and/or muscovite), and the mineral jarosite.

SWIR spectral absorption features used to map argillic and phyllic hydrothermally altered rocks are caused by Al-O-H and O-H molecular vibrations (fig. 2; Hunt, 1977; Hunt and Ashley, 1979). Sericite and smectite have a distinct Al-O-H spectral absorption feature at $2.2 \mu \mathrm{m}$. Alunite exhibits a strong Al-O-H spectral absorption feature at $2.165 \mu \mathrm{m}$ and a weaker Al-O-H spectral absorption feature at $2.2 \mu \mathrm{m}$ and kaolinite exhibits a weak Al-O-H spectral absorption feature at $2.165 \mu \mathrm{m}$ and a stronger Al-O-H spectral absorption feature at $2.2 \mu \mathrm{m}$ (fig. 2; Hunt, 1977; Hunt and Ashley, 1979; Rowan and others, 2003). Jarosite has a distinctive O-H spectral absorption feature at $2.26 \mu \mathrm{m}$ (fig. 2; Hunt and Ashley, 1979; Rowan and others, 2006). ASTER SWIR bands 4, 5, 6, 7 and 8 are centered at $1.65,2.165,2.2,2.26$ and $2.33 \mu \mathrm{m}$, respectively (fig. 2; Fujisada, 1995). ASTER bands 4 through 7 have sufficient spectral resolution to define Al-O-H spectral absorption features of alunite, kaolinite, smectite, and sericite, and ASTER bands 6, 7, and 8 have sufficient spectral resolution to distinguish the jarosite $\mathrm{O}-\mathrm{H}$ spectral absorption feature (fig. 2; Mars and Rowan, 2006; Rowan and others, 2003, 2006). Thus, ASTER SWIR data have has sufficient spectral resolution to map SWIR spectral absorption features exhibited by argillic and phyllic mineral groups and the mineral jarosite.

\section{Data and Methods}

\section{Methodology for Selection and Prioritization of Volcanoes}

To select and prioritize volcanoes with the most densely populated areas, the Smithsonian Institution Global Volcanism Program (GVP) dataset, and a global information system (GIS) global population data set (Landscan ${ }^{\mathrm{TM}}$ ) were used to determine volcano location and population density and distribution within a 50-km radius for each volcano (Bhaduri and others, 2007; GVP database is available at http://www.volcano. si.edu/search_volcano.cfm). The 50-km radius was selected on the basis that most lahars extend less than $50 \mathrm{~km}$ from their origin, but there are some lahars that have traveled over $50 \mathrm{~km}$ (Manville, 2004; Siebe and others, 1996; Vallance and Scott, 1997; Vallance, 2005). The Landscan ${ }^{\mathrm{TM}}$ population density dataset consists of the number of people estimated to inhabit each 1-km-by-1-km resolution raster cell. Landscan ${ }^{\mathrm{TM}}$ population data were compiled from remote sensing data that includes lights at night, topographic slopes, roads, and crop patterns, coupled with census and statistical information from land cover and land use analysis (Bhaduri and others, 2007).

A list of stratovolcanoes from the GVP database was used to identify the type and location of volcanoes worldwide (http://www.volcano.si.edu/search_volcano.cfm). Stratovolcanoes were selected from the database because they are more susceptible to lahars and avalanches than other types of volcanoes due to their large size, frequent eruptive activity, volcanic rock composition, and typically steep slopes. The population data for each stratovolcano was then sorted from the highest population to lowest population using a digital worksheet. In the first year of the study, 98 of the most densely populated volcanoes that had sufficient bare rock exposure were selected from this list (http://ava.jpl.nasa.gov/recent_alteration_zones. php). Evaluation of volcanoes for sufficient rock exposure was done by visual analysis of Google Earth and ASTER images. Mount Adams, Washington, and Mount Jefferson, Oregon, were included due to their relatively accessible locations in the United States, despite having few nearby population centers.

\section{Calibration of ASTER Data}

ASTER Level 1B radiance data were converted to reflectance data for mapping SWIR spectral absorption features and producing alteration maps (Mars and Rowan, 2010). The 30-m spatial resolution SWIR data were resampled to $15-\mathrm{m}$ spatial resolution and combined with the VNIR data. The radiance data were corrected for crosstalk and radiance coefficient anomalies (Mars and Rowan, 2010). ASTER does not have a spectral band in the 0.9 to $1.20-\mu \mathrm{m}$ region to use for determining water vapor values for atmospheric removal calculations and, thus, Moderate Resolution Imaging Spectrometer (MODIS) MOD_05 precipitable water vapor data were used in conjunction with atmospheric removal software to convert ASTER Level 1B radiance data to reflectance data (ImSpec LLC, 2004; Mars and Rowan, 2010). MODIS flies aboard the Terra satellite platform with ASTER, and both instruments simultaneously acquire multispectral image data, such that the 1-km MOD_05 precipitable water vapor and ASTER Level 1B data are both acquired at the same time.

\section{Georegistration of ASTER Reflectance Data}

Individual ASTER scenes used in this study were recorded at four different viewing angles ranging from nadir to $8.2^{\circ}$ off 


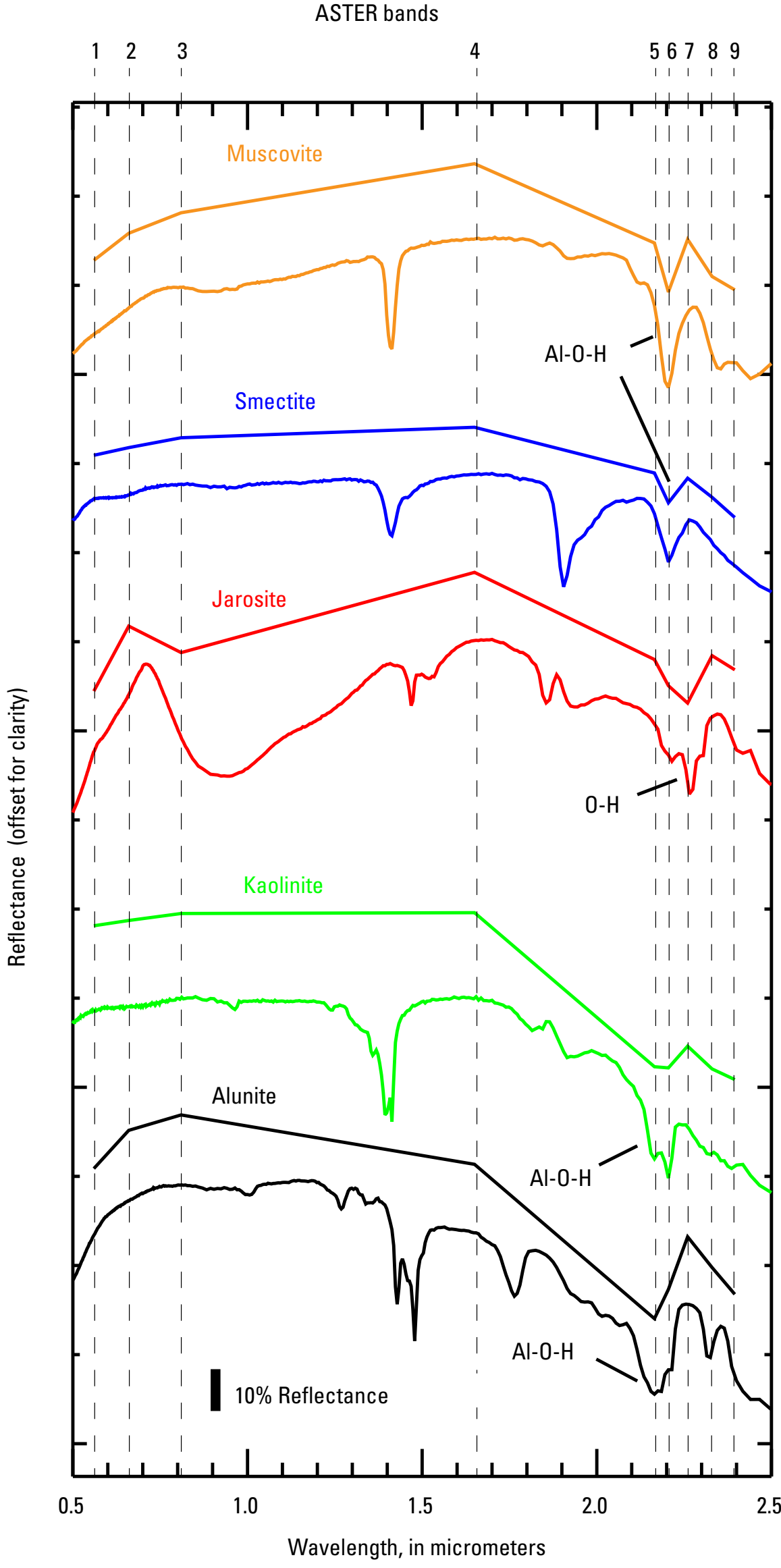

Figure 2. Plot showing reflectance spectra of lab samples and ASTER (Advanced Spaceborne Thermal Emission and Reflection Radiometer) convolved spectral pairs of muscovite (sericite) smectite, jarosite, alunite and kaolinite. This project maps spectral absorption features illustrated by notable reductions in reflectance in ASTER bands 5, 6, 7, and 8 , which are related to the vibration of molecular bonds between aluminum and hydroxide $(\mathrm{Al}-\mathrm{O}-\mathrm{H})$ and between hydrogen and oxygen $(\mathrm{O}-\mathrm{H})$ in certain minerals. Lab sample and ASTER convolved spectral pairs of muscovite (sericite) smectite, jarosite, alunite and kaolinite. 
nadir, which causes misregistration of up to $600 \mathrm{~m}$ in high relief terrain due to parallax displacement. Therefore, each ASTER 9-band reflectance dataset was geometrically registered to an orthorectified Landsat Thematic Mapper (TM) mosaic (Tucker, and others, 2004). The Landsat TM mosaic data have a spatial resolution of $28 \mathrm{~m}$ and horizontal registration accuracy of $\pm 50 \mathrm{~m}$. Although this registration procedure corrected for the off-nadir viewing offset, the ASTER images were not corrected for terrain displacement. Using a either a first rotation or second order polynomial warp registration algorithm and at least 9 ground control points for each scene, we were able to limit root mean square errors to less than $60 \mathrm{~m}$.

ASTER scenes that could not be accurately georegistered using Landsat TM mosaic data were georegistered to an orthorectified image from the AST14OTH ASTER dataset downloaded from the Land Process Distributed Active Archive Center (LPDAAC, https://lpdaac.usgs.gov/). Use of a triangular registration algorithm and at least 900 ground control points for each scene typically limited errors to less than $60 \mathrm{~m}$. All georegistration was done using ENVI ${ }^{\circledR}$ image processing software (Excelis, 2008).

\section{GDEM Data-Description and Uses}

ASTER GDEM data are used to compile slope maps, to classify hydrothermal alteration data by slope, to generate shaded relief maps, to compile stream flow lines, and for GIS computer flow modeling of potential lahar inundation zones (Hubbard and others, 2007). ASTER data from band 3 and the backward looking stereo band $3 \mathrm{~b}$ are used to compile the global digital elevation model database which is available at no charge through the Earth Remote Sensing Data Analysis Center (ERSDAC) and LPDAAC Web sites (http://asterweb.jpl. nasa.gov/gdem.asp). Land coverage of the ASTER GDEM is continuous between $83^{\circ} \mathrm{N}$ and $83^{\circ} \mathrm{S}$ and is composed of 22,600 $1^{\circ}$-by- $1^{\circ}$ tiles. The ASTER GDEM product is in GeoTIFF format with geographic latitude/longitude coordinates and a 1 arcsecond $(30 \mathrm{~m})$ grid of elevation postings. Estimated accuracies for this global product are \pm 20 meters at 95 percent confidence for vertical accuracy and \pm 30 meters at 95 percent confidence for horizontal registration accuracy (ASTER GDEM Validation Team, 2009).

\section{Hydrothermal Alteration Mapping Algorithms}

For this study, 100 hydrothermal alteration maps of volcanoes were compiled using Interactive Data Language (IDL ${ }^{\circledR}$ ) logical operators. Logical operator algorithms were used to map rocks displaying argillic, phyllic and jarosite absorption features using ASTER VNIR 15-m resolution and resampled SWIR 30-m reflectance data, and ENVI ${ }^{\circledR}$ processing software based on the following three logical operators (eqn.1, argillic; eqn. 2, phyllic; eqn. 3 , jarosite) modified from previous ASTER mineral mapping studies (Excelis, 2008; John and others, 2010; Mars and Rowan, 2006):
Equation 1, for argillic minerals ((float(b3)/b2) le 1.35) and (b4 gt 1600) and ((float(b4)/b6) gt 1.35) and ((float(b5)/b6)le 1.089) and $(($ float(b7)/b6) gt 1.0)

Equation 2, for phyllic minerals ((float(b3)/b2) le 1.35) and (b4 gt 1600) and ((float(b4)/b6) gt 1.35) and ((float(b5)/b6)gt 1.089) and ((float(b7)/b6) gt 1.0)

Equation 3, for jarosite ((float(b3)/b2) le 1.35) and (b4 gt 1600) and ((float(b4)/b6) gt 1.35) and ((float(b6)/b7) ge $1.026)$ and ((float(b8)/b7) ge 1.029)

where

$\begin{aligned} \text { b } & \text { is ASTER band number; } \\ \text { ge } & \text { is greater than or equal to; } \\ \text { gt } & \text { is greater than; } \\ \text { le } & \text { is less than or equal to; } \\ \text { float } & \text { is the calculation to be done using floating } \\ & \text { point numbers }\end{aligned}$

These logical operator algorithms use a series of band ratios and user-defined thresholds to map spectral absorption features and to mask low-reflectance and noisy pixels. Threshold numbers for band ratios and band threshold values were determined by compiling ASTER argillic and phyllic mineral maps for well-known calibration-validation sites in Cuprite, Nevada, and Mountain Pass, California (Mars and Rowan, 2010). Hyperspectral and field mineral maps from previous studies at Mount Shasta, California, and Pico De Orizaba, Veracruz-Puebla, Mexico, were also used to modify band thresholds (figs. 1 and 3; CarrascoNúñez and others, 2006; Crowley and others, 2003; Hubbard, 2001).

Because ASTER VNIR and SWIR bands measure reflective radiation, only surficial spectral information is collected. Altered rocks covered in snow, ice, clouds or vegetation cannot be measured. In addition, low reflectance, spectrally noisy areas such as water, damp soils, and shadowed areas can produce erroneous results and were omitted. The logical operator algorithms mask green vegetation by utilizing the chlorophyll absorption feature at $0.65 \mu \mathrm{m}$ using an ASTER 3/2 band ratio (eqns. 1-3). Water, snow, and noisy, low reflectance pixels were eliminated in logical operators by using a threshold of ASTER band 4 scaled reflectance values centered at $1.65 \mu \mathrm{m}$ (eqns. 1-3).

The argillic logical operator (eqn. 1) maps the 2.165and 2.2- $\mu \mathrm{m}$ Al-O-H absorption features exhibited by argillic-altered rocks using 4/6, 5/6, and 7/6 ASTER band ratios (fig. 2). The phyllic logical operator (eqn. 2) maps the 2.2- $\mu \mathrm{m}$ Al-O-H absorption feature illustrated by phyllicaltered rocks using the same $4 / 6,5 / 6$, and 7/6 ASTER band ratios that are used to map argillic altered rocks. The $5 / 6$ band ratio threshold for the phyllic algorithm, however, is higher than the $5 / 6$ band ratio value for the argillic 


\section{$\boldsymbol{A}$}

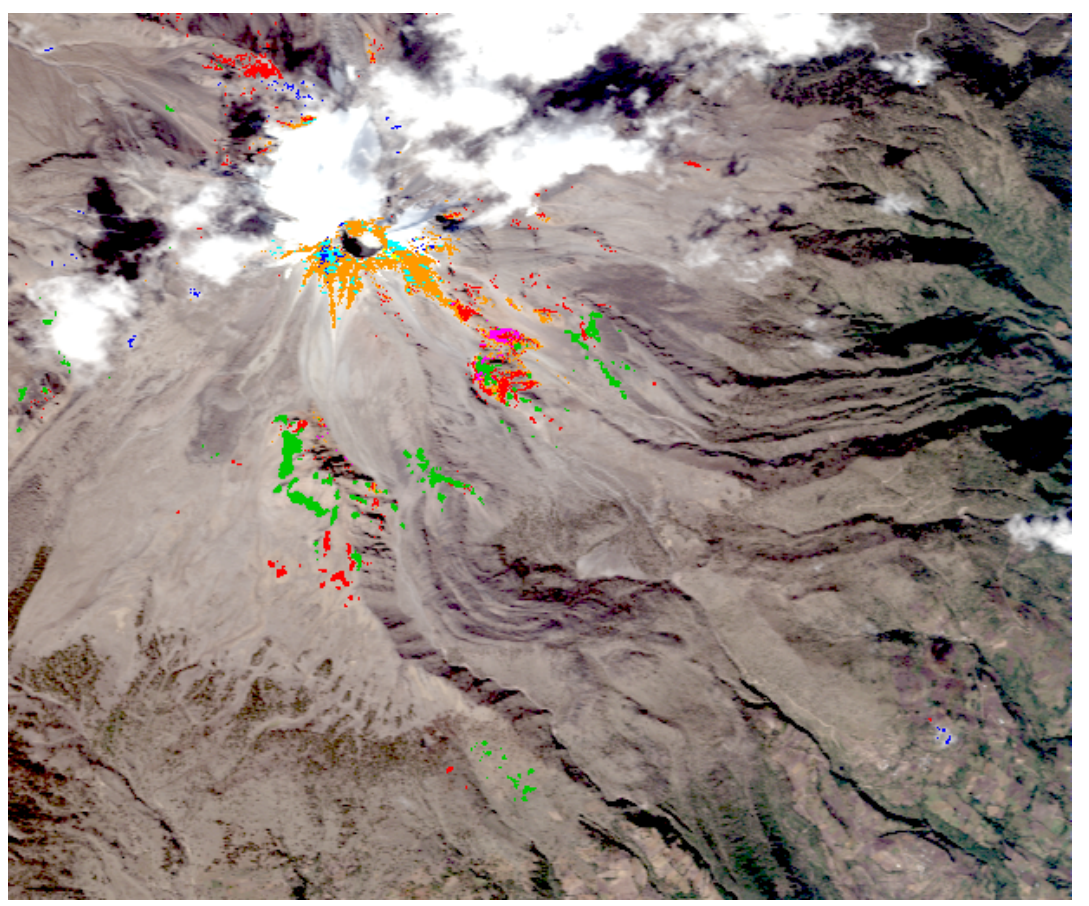

B

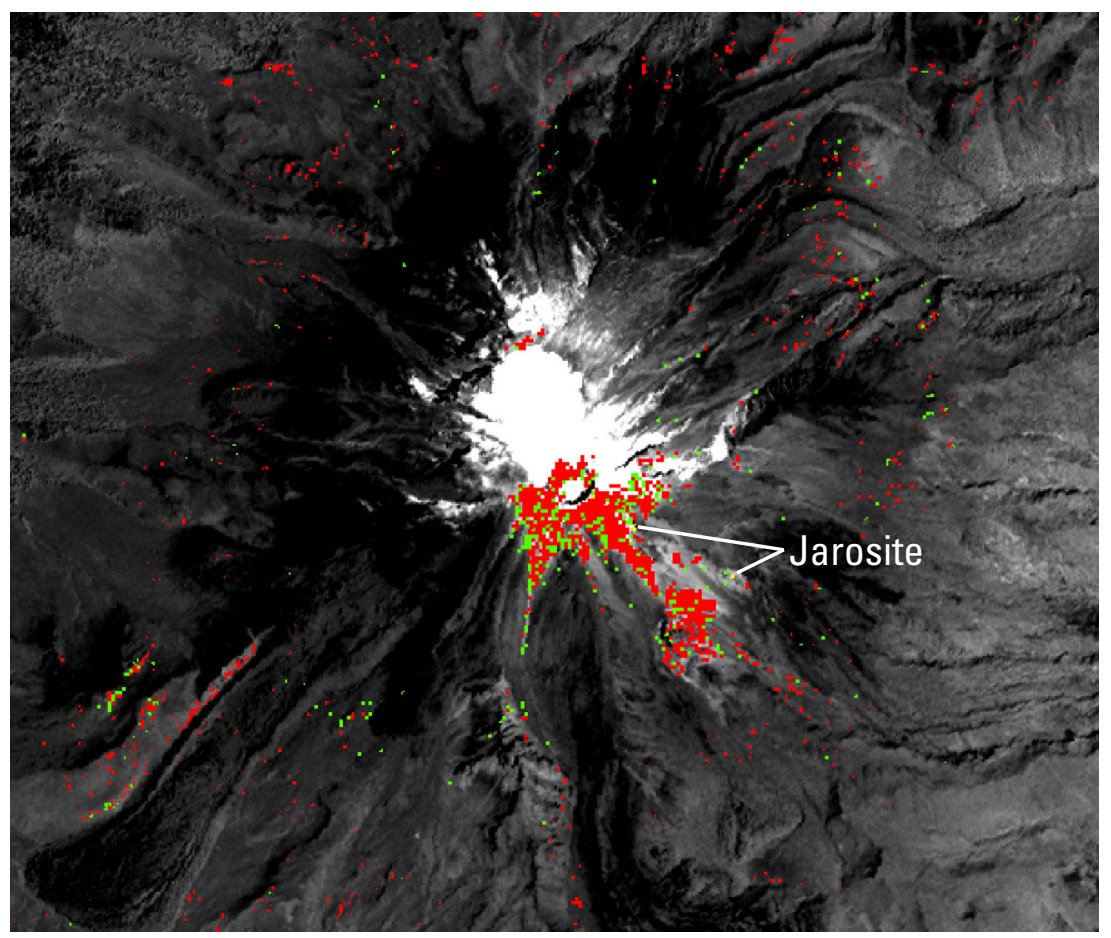

\section{AVIRIS mineral map:}

Kaolinite

Natroalunite + other sulfates

Kaolinite + natroalunite + smectite

Opaline silica

Hematite (coarse \& specular)

Goethite + hematite

Jarosite + other ferric iron

$\mathbf{N}$

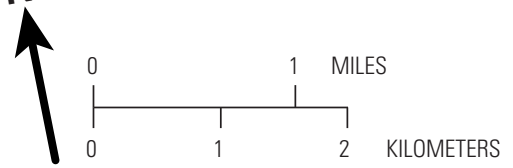

\section{ASTER mineral map:}

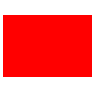

Argillic-altered rocks (alunite, kaolinite)

Phyllic-altered rocks (muscovite, smectite)

Jarosite-rich rocks

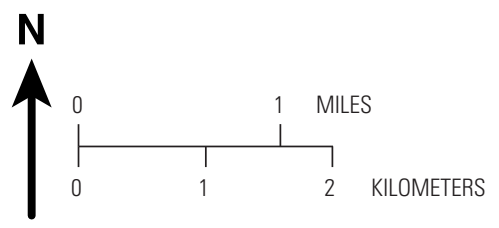

Figure 3. Comparison of two maps of Pico de Orizaba, Mexico, showing minerals associated with hydrothermal alteration, made using spectral data from AVIRIS (Airborne Visible/Infrared Imaging Spectrometer) and ASTER (Advanced Spaceborne Thermal Emission and Reflection Radiometer). A, Alteration mineral map from AVIRIS data. Argillic minerals include kaolinite and natroalunite (yellow, blue, and orange). Background image is a composite of AVIRIS visible Landsat-equivalent wavelength channels, stretched to simulate true color. $B$, Alteration mineral map from ASTER data, illustrating argillic-altered rocks (red), phyllic-altered rocks (green) and jarosite-rich rocks (yellow). Background image is ASTER band 3 . 
Lahar Inundation Maps of Volcanoes for the ASTER Volcanoes Archive

algorithm (eqns. 1 and 2). The jarosite logical operator (eqn. 3) maps the $2.26-\mu \mathrm{m} \mathrm{O}-\mathrm{H}$ absorption feature using $6 / 7$ and $8 / 7$ ASTER band ratios (fig. 2).

Although the ASTER VNIR reflectance data set has a spatial resolution of $15 \mathrm{~m}$, the mapped hydrothermal alteration units have 30-m spatial resolution because the Al-O-H and $\mathrm{O}-\mathrm{H}$ spectral absorption features are mapped using the SWIR 30-m resolution data. The SWIR data are resampled from 30-m spatial resolution to $15 \mathrm{~m}$ and combined with the VNIR data so that the VNIR and SWIR spectral absorption features can be mapped using a single algorithm. The resulting logical operator mineral bit maps consist of raster data containing pixels with values of 0 or 1 , which were then converted to vector data for import into other datasets and maps.

Although in other studies smectite has been classified as intermediate argillic alteration, the phyllic logical operator maps smectite as phyllic alteration in this study because they have similar $2.2 \mu \mathrm{m}$ spectral absorption features and there is not enough spectral variation in ASTER VNIR-SWIR data using the current spectral regional mapping techniques to distinguish smectite from sericite (fig. 2; John and others, 2008, 2010). Thus, in this study, the phyllic unit may also include the intermediate argillically altered mineral smectite.

\section{Validation of Hydrothermal Alteration Mapping}

To validate alteration mapping on volcanoes, AVIRIS mineral maps and field data of volcanic edifices for Mount Shasta, California, and Pico de Orizaba, Veracruz-Puebla, Mexico, were compared to ASTER-mapped argillic, phyllic and jarosite maps of the same areas (figs. 1 and 3). The ASTER and AVIRIS mineral maps for Mount Shasta and Pico De Orizaba show good agreement in mapping almost 100 percent of the argillic altered rocks around the summit areas (figs. 1 and 3; Crowley, and others, 2003; Hubbard, 2001).

Mount Shasta shows more argillic alteration on the southeastern parts of the lower slopes in the ASTER mineral map, which is because of greater snow cover in the AVIRIS image and lower threshold values used to map altered rock in the ASTER data (fig. 1). The lower threshold values result in mapping more weakly hydrothermally altered rocks than were mapped using AVIRIS data (eqs. 1-3). Although the argillicaltered rocks on the southeastern lower slopes of Mount Shasta are not mapped in the AVIRIS image, the ASTER-mapped altered rock units in this area exhibit prominent 2.165- and 2.2- $\mu \mathrm{m}$ spectral absorption features, which are diagnostic of hydrothermally altered rocks (figs. 2 and $4 A$ ). Jarosite was also mapped in small areas on Mount Shasta. An average image spectrum of jarosite-mapped areas shows a prominent 2.26- $\mu \mathrm{m}$ spectral absorption feature (figs. 2 and $4 A$ ).

Phyllic alteration that was mapped on Mount Shasta, using ASTER data, was not mapped using AVIRIS data (fig. 1). In some areas, scarce phyllic rocks are interspersed with argillic rocks and may indicate areas where mineral mixing, data noise, and insufficient data calibration are interfering with the discrimination of argillic from phyllic units. This incoherent pattern of phyllic-altered rocks is caused by the low spectral resolution of ASTER SWIR data in comparison to AVIRIS data, in which the discrimination between argillic and phyllic units is dependent on a single 5/6 ASTER ratio. Even though the ASTER algorithm may have incorrectly mapped some of the argillic-altered rocks as phyllic-altered rocks, the areas mapped as phyllic-altered rocks match AVIRIS-mapped areas of hydrothermally altered rocks, which is the primary focus of the study.

At Pico de Orizaba, there is significantly less jarosite in the ASTER mineral map than in the AVIRIS mineral map (fig. 3). In addition, several areas are mapped in the AVIRIS data as goethite- and hematite-rich rocks whereas in the ASTER image those areas are mapped as primarily argillic rocks (fig. 3). Sample spectral data collected from Pico de Orizaba indicate that the lack of jarosite in the ASTER mineral map is mostly due to mixing of the jarosite, alunite, goethite and hematite (fig. 4B; Hubbard, 2001). The ASTER mapping algorithm only maps kaolinite-alunite because the logical operator algorithm maps the argillic SWIR absorption component of the hydrothermally altered rocks instead of the VNIR spectral absorption features of goethite and hematite, which are situated at $0.9 \mu \mathrm{m}$. The Pico de Orizaba AVIRIS mineral map was generated using spectral unmixing methods that considered spectral absorption features across a wider range of wavelengths, including the VNIR spectral region for which ferric iron minerals tend to dominate over any clay or sulfate mineral present (Hubbard, 2001). The lower proportion of jarosite illustrated on the ASTER mineral map compared to the AVIRIS mineral map is also due to spectral mixing of alunite and jarosite, which has subdued the Al-O-H and O-H spectral absorption features (fig. 4; Hubbard, 2001).

\section{Slope-Classified Hydrothermal Alteration}

Alteration units consisting of argillic, phyllic and jarosite-bearing rocks are classified by surface slope in order to determine areas that have the greatest potential risk of edifice collapse. Areas considered at greatest risk for generating rock avalanches and lahars consist of hydrothermally altered bedrock on slopes greater than their depositional angle of repose (Watters and others, 2000). At Mount Shasta, the angle of repose that separates bedrock cliffs from talus slopes is approximately $35^{\circ}$ (Crowley and others, 2003). In this study, three slope-classified units were selected based on the depositional angles of repose derived from ASTER GDEM data. Thus, surface slopes $>35^{\circ}$ were interpreted to consist primarily of exposed hydrothermally altered bedrock, surfaces with slopes of $35-30^{\circ}$ represent a transition zone from mostly bedrock to talus-covered slopes, and surfaces with slopes $<30^{\circ}$ are interpreted to consist of mostly talus.

Slope maps were compiled from ASTER GDEM data and slope masks were generated using ENVI ${ }^{\circledR}$ imaging 
A Averaged ASTER image spectra ASTER bands

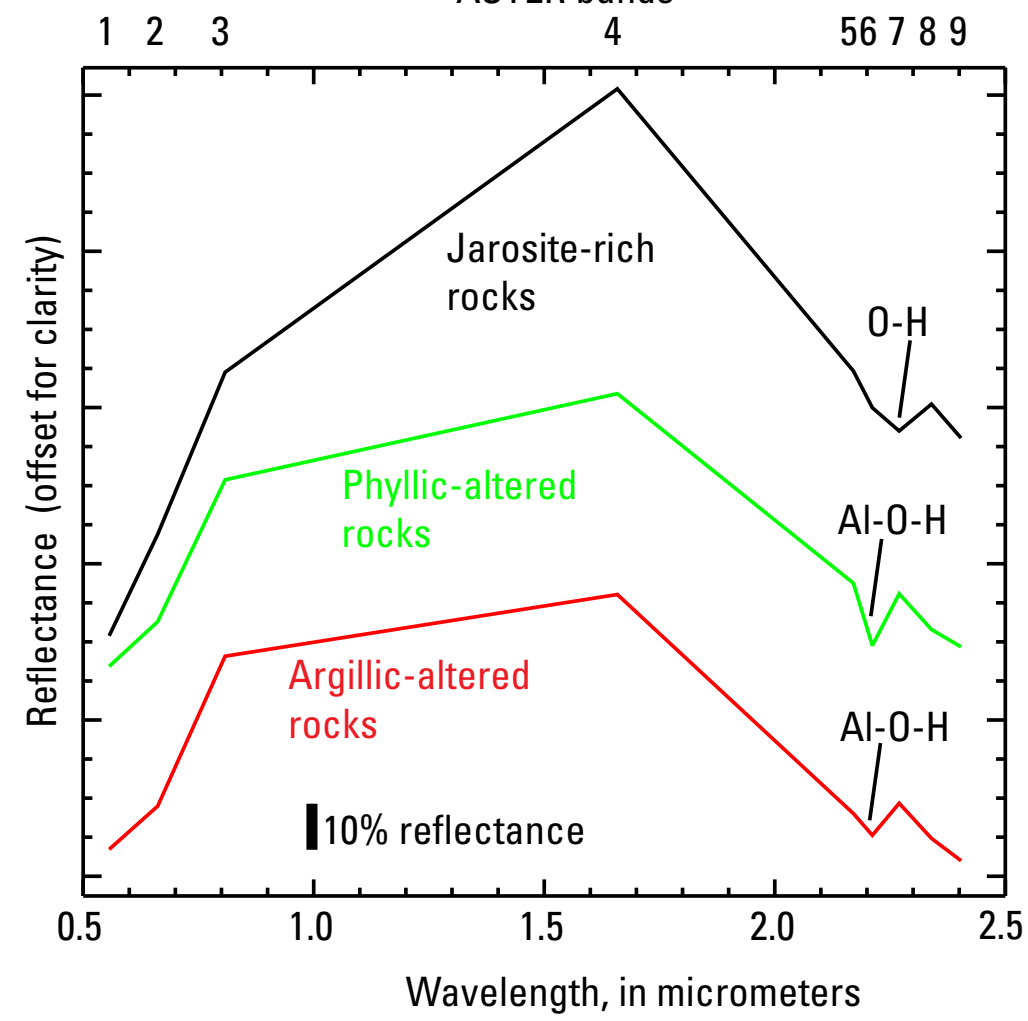

Figure 4. A, A plot of ASTER (Advanced Spaceborne Thermal Emission and Reflection Radiometer) image reflectance spectra of the lower southeastern slopes of Mount Shasta, California. The spectra are spectral averages $(n=$ number of pixels mapped) for argillic-altered rocks $(n=17,184)$, phyllic-altered rocks $(n=1,612)$ and jarosite-rich rocks $(\mathrm{n}=8)$. $B$, Sample spectra from the U.S. Geological Survey spectral library of alunite, kaolinite, and jarosite, a spectrum from sample TR005B from Pico de Orizaba, and composite spectrum from U.S. Geological Survey spectral library of mixed alunite and jarosite (from Hubbard, 2001).

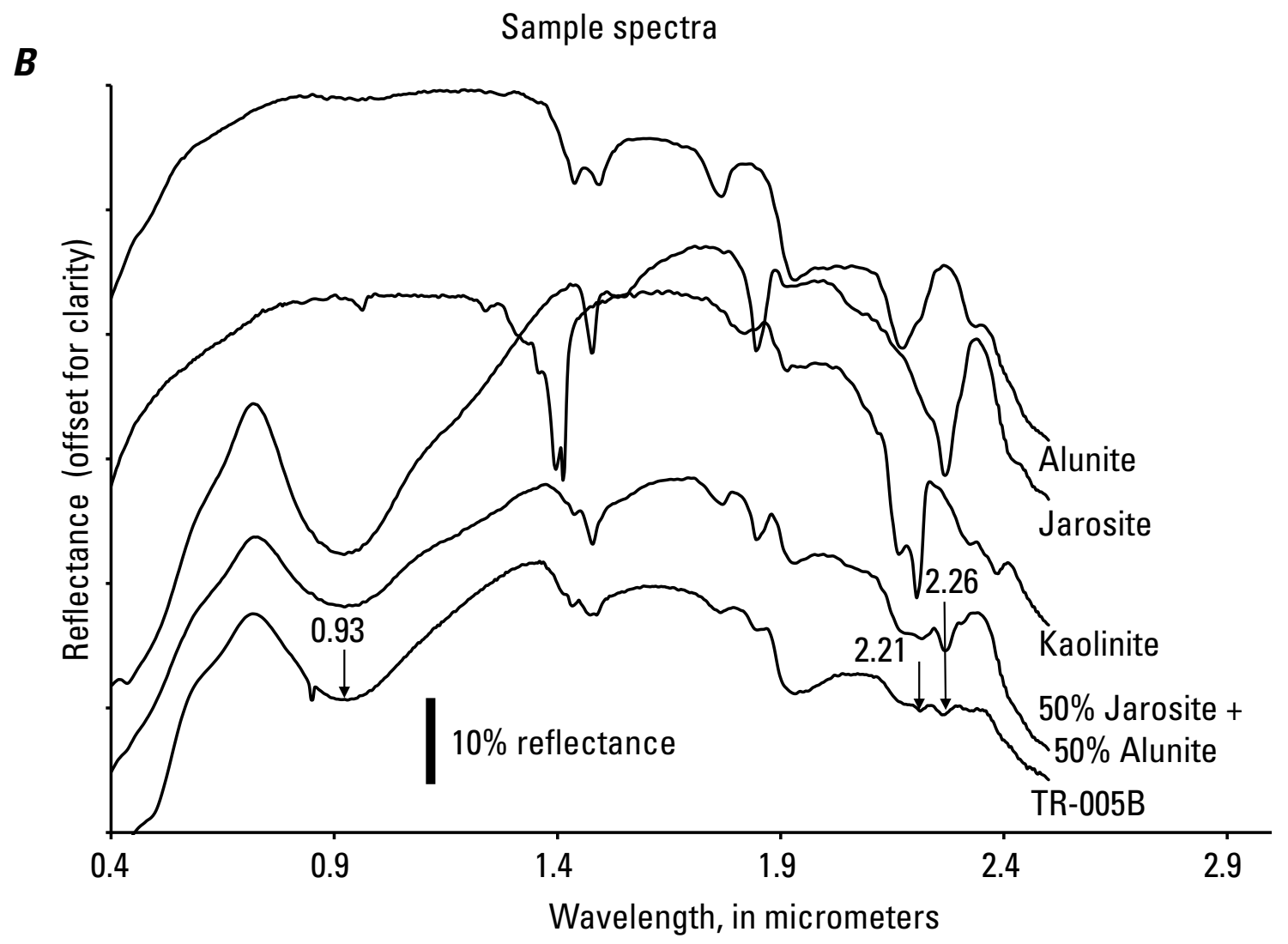


processing software (Excelis, 2008). Masks for slopes steeper than $35^{\circ}, 30^{\circ}$ to $35^{\circ}$, and less than $30^{\circ}$ were applied to hydrothermal alteration maps to produce slope classified datasets.

\section{Lahar Type Used for Modeling of Potential Inundation Areas}

Edifice-collapse-induced lahars are debris flows that originate as avalanching debris that contains enough water to liquefy, often beginning as a clay-rich slurry (Vallance, 2000). These flows are typically large volume, such as the Osceola mudflow from Mount Rainier 5,600 years ago, which flowed into the Puget Sound with an estimated volume of 4 billion $\mathrm{m}^{3}$ (Vallance and Scott, 1997). In general, edifice-collapse-induced lahars are more common at glaciated and snow-covered volcanoes, where there are usually ample amounts of meltwater from snow and ice to water-saturated clay-rich hydrothermally altered rock and sediment. Lahars may also originate as a liquefaction slide, like at Mount Meager, British Columbia, when several smaller rock slides of hydrothermally altered rocks transformed directly into debris flow slurries through liquefaction, including a 49 million- $\mathrm{m}^{3}$ flank failure that occurred on August 6, 2010 (Guthrie and others, 2012). The flank collapse volume was derived by computing the difference between DEMs generated both before and after the collapse event (Guthrie and others, 2012). Also, the initial failure mass had completely disintegrated and become fluidized at the source by mixing with pore water contained in the saturated source bedrock areas (Guthrie and others, 2012).

Because this study focuses on mapping hydrothermally altered rocks and their relationship to lahars, we model lahar inundation areas for Mount Shasta in northern California, Mount Hood in northern Oregon, and Iztaccíhuatl volcano, Mexico, that could result from clay-rich, edifice- or flankcollapse-induced lahars. To estimate lahar inundation areas, we assume that mapped hydrothermally altered bedrock areas are water-saturated enough to liquefy directly into lahars. Also, we assume that the resulting clay-rich lahars will not transform into more dilute flow types, and will not substantially volumetrically increase in bulk downstream, which is typical of these types of flows (Vallance and Scott, 1997). Our lahar inundation maps do not apply to avalanche lahar processes related to clay-poor lahars, typically triggered by eruptions, or rain-triggered lahars mobilizing pyroclastic deposits on steep slopes (Vallance, 2000).

\section{LAHARZ Model, Methods, and Uncertainties}

Lahars were modeled using the "LAHARZ" GIS code (Iverson and others, 1998; Schilling, 1998). Since completion of this study in 2013, a new lahar modeling program (LAHAR_pz) has been released, which may produce slightly different modeling results from the LAHARZ model used in this study (Schilling, 2014).

LAHARZ routes user-input lahar source volumes downstream using hydrologic grids and hydrographic networks derived from ASTER GDEM data. The model is based on a log-linear scaling relationship between lahar volume and the cross-sectional and planimetric areas of inundation, using a statistical database of debris flows of various sizes and extents studied throughout the world (Iverson and others, 1998). LAHARZ also provides fully automated extraction of hydrographic networks, which are especially customized for the unique topography and geomorphology of most volcanoes, as well as potential inundation zones that can be rendered into various raster or vector formats for GIS.

The geometry and resulting volumes of material derived from volcano sector collapses is complex and often influenced by a range of geotechnical factors such as rock strength, cohesion, and internal angle of friction, as well as structural considerations like the magnitude of mass loading, preexisting faults and fractures, and over-steepened slopes from glacial erosion (Watters and others, 2000). Internal stressors such as pore fluid pressure and magmatic intrusions such as cryptodomes and (or) accompanying eruptions of overlying lava flows and pyroclastic deposits need to be considered as well (Voight and Elsworth, 1997; van Wyck de Vries and Francis, 1997; van Wyck de Vries and others, 2000; Reid and others, 2000, 2006). Wedge collapse models such as SCOOPS have been used to determine volumes of flank collapse materials using the parameters described above (Reid and others, 2000; Reid and others 2006). Because we lack such detailed information about the internal structure, stratigraphy, and hydrology for most of the volcanoes around the world, we use a simple geometric model in which the vertical detachment zone is at a $90^{\circ}$ angle from a horizontal basal decollement zone (fig. 5; Crowley and others, 2003). The volumes of altered rocks were compiled using areas of hydrothermally altered rocks on slopes $>35^{\circ}$ and extrapolated to the basal decollement level elevations approximated by the lowermost extent of exposed hydrothermally altered rocks (fig. 5; Crowley and others, 2003). Thus, the geometry of the hydrothermally altered rock volume is a wedge bounded by a hydrothermally altered surface, a base level floor, side walls projecting toward the volcano central axis, and a vertical interior wall (fig. 5; Crowley and others, 2003). The advantage of this simpler geometric and structural model is that the calculated volume reflects the maximum volume available based on the surficial, exposed, hydrothermally altered rocks, and is easily and rapidly calculated using the standard terrain analysis functions within ArcGIS. In addition, modeled areas of inundation from lahars for Iztaccíhuatl are consistent with areas impacted by ancient lahars (for example, Siebe and others, 1996).

Because we use the maximum angle between the vertically approximated detachment zone and horizontally approximated decollement zone, the volumes we derive can be considered to be larger than those produced by a typical arcuate-wedge slope failure. However, our volume estimates include only those altered rocks underlying ASTER-mapped altered areas. Altered rocks concealed by snow, ice, glaciers, vegetation and even thin veneers of fresh ash and tephra deposits cannot be mapped and, thus, are not incorporated into our volume estimates. For example, at the pervasively altered 
Avalanche Glacier scarp area of Mount Adams, Crowley and others (2003) estimated a volume of altered rock $\sim 0.5 \mathrm{~km}^{3}$, using the simple $90^{\circ}$ failure geometry described above. Using airborne geophysical data, Finn and others (2007) calculated a volume of $\sim 1.8 \mathrm{~km}^{3}$ for this same electro-magnetic lowresistivity and magnetic low-susceptibility area. The difference between the volume calculated by Finn and others (2007) using subsurface geophysics is more than three times that calculated by Crowley and others (2003) using combined remote sensing and DEM mapping as described above; though both estimates are less than the $3.3 \mathrm{~km}^{3}$ maximum volume originally estimated by Vallance (1999) for the entire summit area (note that Vallance, 1999 also estimated a minimum volume of $\left.0.9 \mathrm{~km}^{3}\right)$. Thus, in some cases, LAHARZ input volumes are minimum estimates, and an actual lahar generated from these areas could be larger than what we model because of the inability of ASTER to detect altered rocks in covered areas.

Two inundation areas were simulated using (1) the original ArcGIS-derived volume of altered rock derived using the ASTER GDEM topographic surface and (2) a 2x volume encompassing the farthest possible inundation extent, as
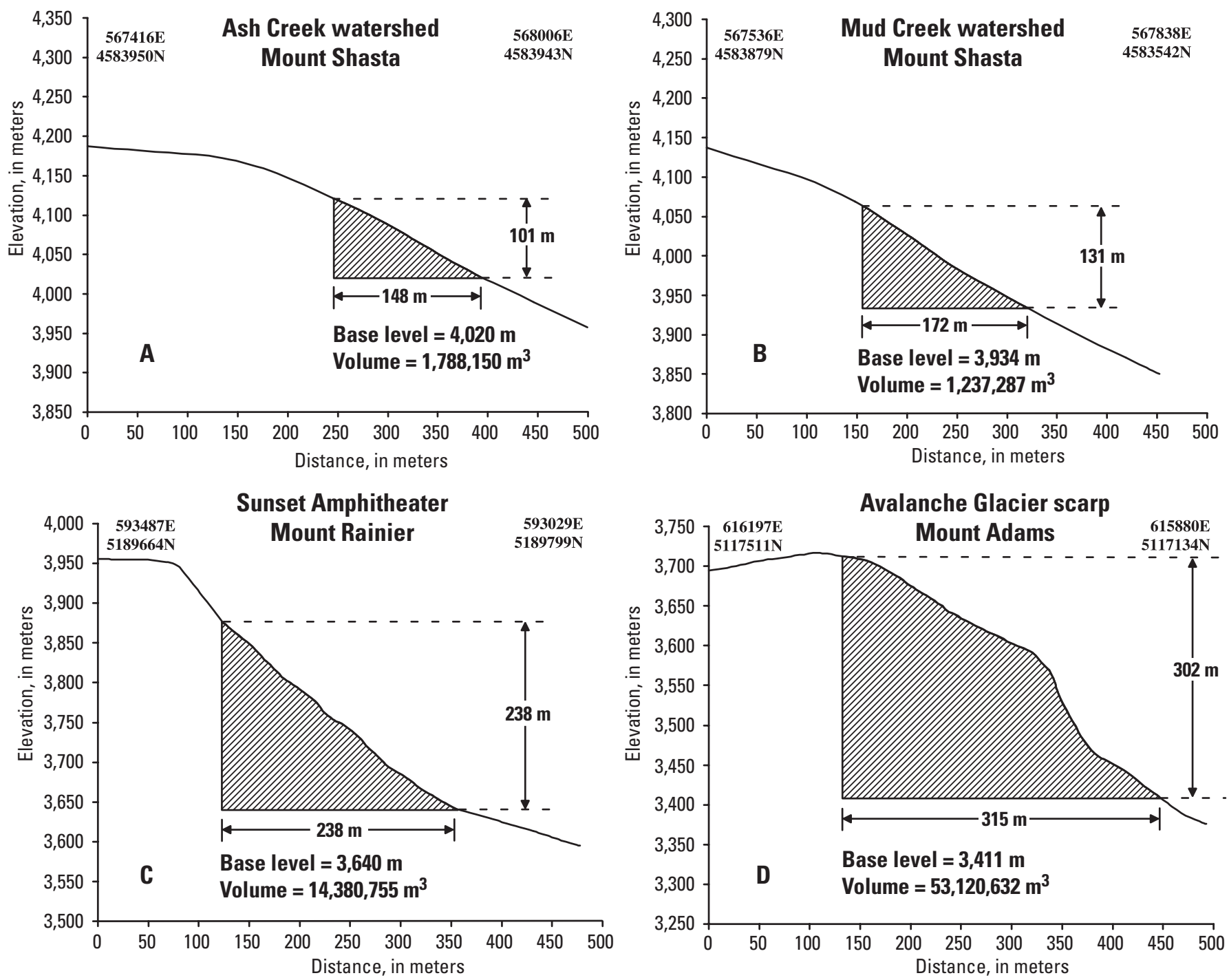

Figure 5. Vertical profiles showing modeled volumes of selected altered rock masses on Mount Shasta, Mount Rainier, and Mount Adams. The model uses AVIRIS (Airborne Visible/Infrared Imaging Spectrometer) spectral data for Mount Shasta and Mount Rainier profiles and uses ASTER (Advanced Spaceborne Thermal Emission and Reflection Radiometer) spectral data for the Mount Adams profile in conjunction with digital elevation data from the U.S. Geological Survey. An irregular triangular network with dense mesh spacing was used to define the surface topography of each rock mass. Altered rock vertical extents and base level elevations were determined from topographic profiles extracted across each of the rock masses. Volumes between the topographic surface and each base level elevation were calculated using ArcINFO ${ }^{\circledR}$. Profile and cross section of modeled volume (shaded) of: $A$, Ash Creek watershed on Mount Shasta's eastern flank; $B$, Mud Creek watershed on the southeast flank of Mount Shasta; $C$, Sunset Amphitheater on Mount Rainier's northwest flank; D, Avalanche Glacier scarp area on the southern flank of Mount Adams (from Crowley, 2003). 
suggested by statistical uncertainties inherent in the LAHARZ model (for example, Iverson and others, 1998; Robinson and Clynne, 2012). Iverson and others (1998) report a standard error of around 30 percent in their equations for calculating cross sectional and planimetric areas of inundation, and note that such errors compounded yield approximately 150 percent error in predicting areas of inundation from specified volumes (Robinson and Clynne, 2012). In our case, we rounded the uncertainty factor up to $2 \mathrm{x}$ to ensure that the full volumetric range of events are covered when trying to map the maximum possible inundation limit from the lahar types we specify in the lahar types section.

Given these unknown factors, our LAHARZ-generated inundation maps should not be used as forecasts or predictions, but as a means of considering the potential effects of hydrothermal alteration on lahar genesis and emplacement.

\section{Products and Delivery}

To effectively display hydrothermal alteration and related potential lahar inundation areas, each volcano has a series of maps that show (1) composition and distribution of hydrothermally altered rocks, (2) distribution of slope-classified hydrothermally altered rocks, with watersheds and populated areas that may be affected, and (3) a false-color composite image indicating bare rock and soil, snow and ice, vegetation, and cloud cover, which shows what parts of the volcano were mapped and not mapped (figs. 6, 7, and 8, respectively). All of these maps can be used to qualitatively determine collapseprone areas on the volcanic edifice and the watersheds that may be affected.

Lahar flow models were completed for Mount Shasta in northern California, Mount Hood in northern Oregon, and Iztaccíhuatl Volcano in central Mexico. These volcanoes exhibit hydrothermal alteration on slopes $>35^{\circ}$ over an area $>0.25 \mathrm{~km}^{2}$ and have nearby populations $>100$ people per $\mathrm{km}^{2}$ that may be affected. Lahar flows based on total DEM-derived altered rock volume and a $2 \mathrm{x}$ uncertainty factor are shown for each volcano on a shaded relief map depicting population, slope classified alteration units, and stream flow lines (fig. 9).

Hydrothermal alteration and lahar inundation units are available for download as shape files and in $\mathrm{kml}$ format. In addition, all raster maps are provided in geotiff and $\mathrm{kml}$ format. All data can be loaded into popular image and GIS software packages such as ArcGIS ${ }^{\circledR}$, Adobe Photoshop ${ }^{\circledR}$, and Google Earth ${ }^{\mathrm{TM}}$. Data products can be accessed from the ASTER Volcano Archive Web site (http://ava.jpl.nasa.gov/ recent_alteration_zones.php).

\section{Results}

In this study we (1) identified and prioritized 720 volcanoes based on population density using the GVP online database and LandScan ${ }^{\mathrm{TM}}$ digital population dataset; (2) validated ASTER hydrothermal alteration mapping techniques using AVIRIS and ASTER data for Mount Shasta and Pico de Orizaba; (3) mapped and slope-classified hydrothermal alteration using ASTER VNIR-SWIR reflectance data on 100 of the most densely populated volcanoes; (4) delineated drainages using ASTER GDEM data that show flow paths of potential lahars for the 100 mapped volcanoes; (5) produced potential lahar inundation maps for Iztaccíhuatl in Mexico and for Mount Hood and Mount Shasta in the United States that illustrate areas likely to be inundated based on our DEM-derived volume estimates and the $2 x$ LAHARZ model uncertainty factor; and (6) saved all image and vector data formats for 3D and 2D display in Google Earth ${ }^{\mathrm{TM}}$, ArcGIS $^{\circledR}$ and other graphics display programs. In addition, all data have been uploaded and are available from the ASTER Volcano Archive Web site (http://ava.jpl.nasa.gov/recent alteration zones.php).

A major concern was that because of snow, ice, clouds, and (or) vegetation cover, there would not be a sufficient number of volcanoes available to map for this study. The GVP catalog of volcanoes (http://www.volcano.si.edu/) was used as the database for identifying and prioritizing volcanoes for hydrothermal alteration mapping. The database currently has approximately 1,500 volcanoes listed (but the total may change from year to year). In the database there are a total of 720 stratovolcanoes listed that have significant populations within a $50-\mathrm{km}$ radius of their volcanic centers. Stratovolcanoes were selected due to their typically larger size and steeper slopes as compared to other volcano types. Of the 720 stratovolcanoes identified and prioritized based on population density in the GVP, 350 of the most densely populated stratovolcanoes were assessed for bare earth exposure using ASTER and Google Earth ${ }^{\mathrm{TM}}$ imagery. Of those 350 volcanoes, 250 volcanoes were not mapped due to excessive snow, ice, and (or) vegetation cover. Results from mapping hydrothermally altered rocks on the remaining 100 stratovolcanoes show that 87 exhibit hydrothermally altered edifices. There are a total of 49 stratovolcanoes that show hydrothermally altered rocks on slopes $>35^{\circ}$ situated above areas with populations $>100$ people per $\mathrm{km}^{2}$. Of the 49 stratovolcanoes, 17 exhibit laterally extensive, hydrothermally altered rocks that cover an area $>0.25 \mathrm{~km}^{2}$ on slopes $>35^{\circ}$ that may pose a significant threat of generating lahars.

Most of the densely populated stratovolcanoes are in forested tropical areas such as Indonesia. Most of the less densely populated stratovolcanoes in the GVP are in areas with less vegetation cover, suggesting that, of the remaining 370 stratovolcanoes not assessed nor mapped, there may be an additional 100-200 stratovolcanoes in the Smithsonian database that may be sufficiently exposed to allow for mapping hydrothermal alteration. This estimate is only for volcanic edifices classified as stratovolcanoes in the GVP database. 






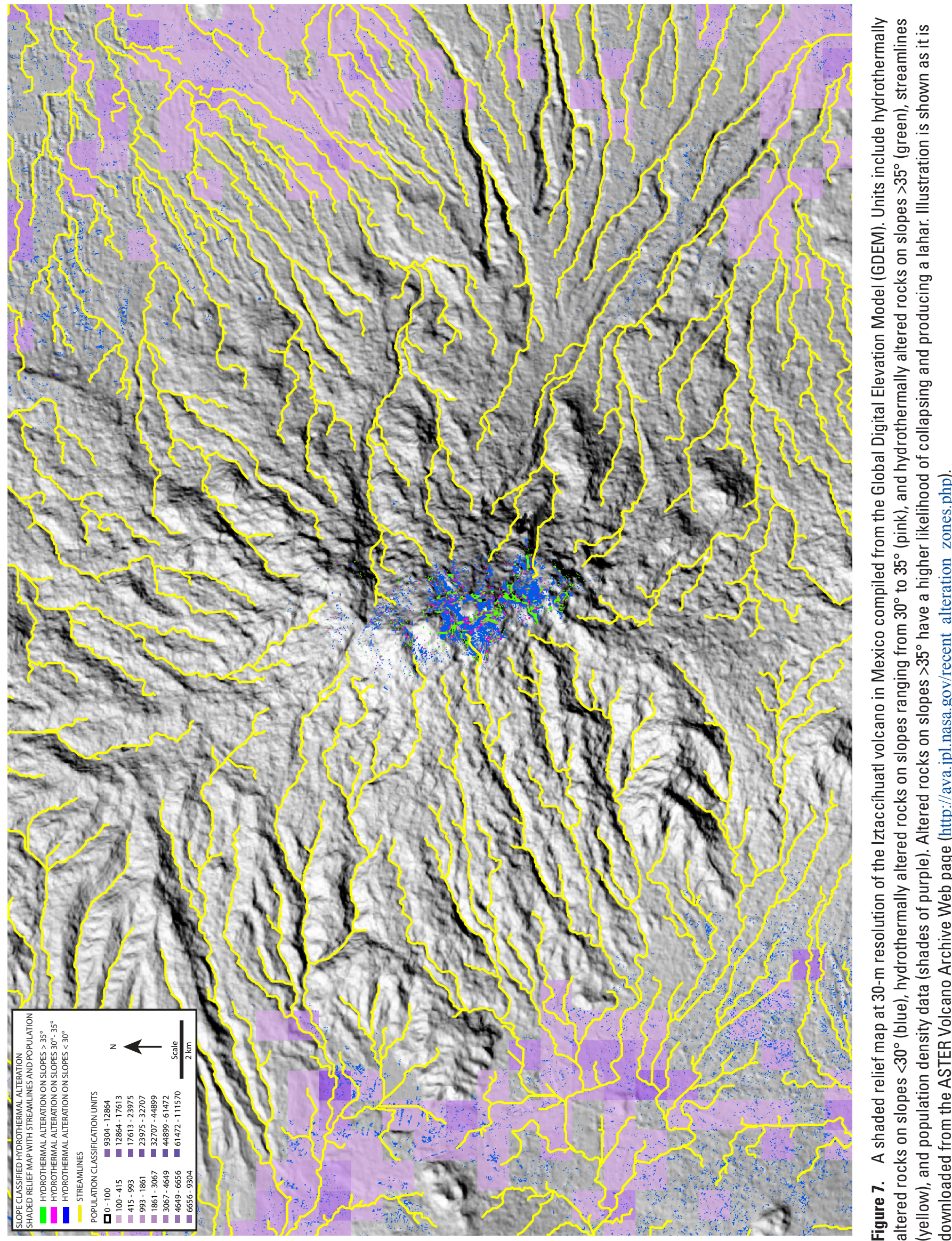


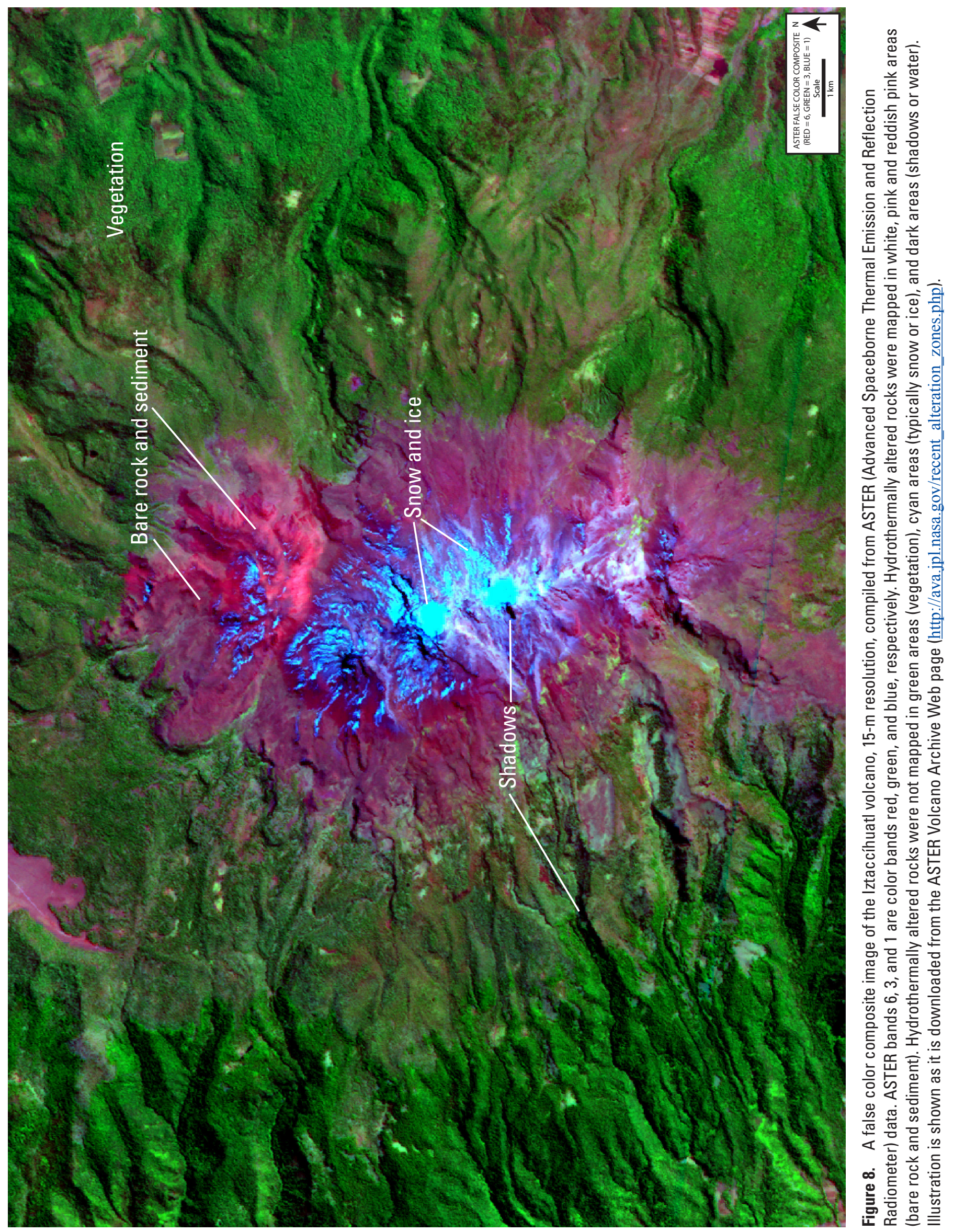




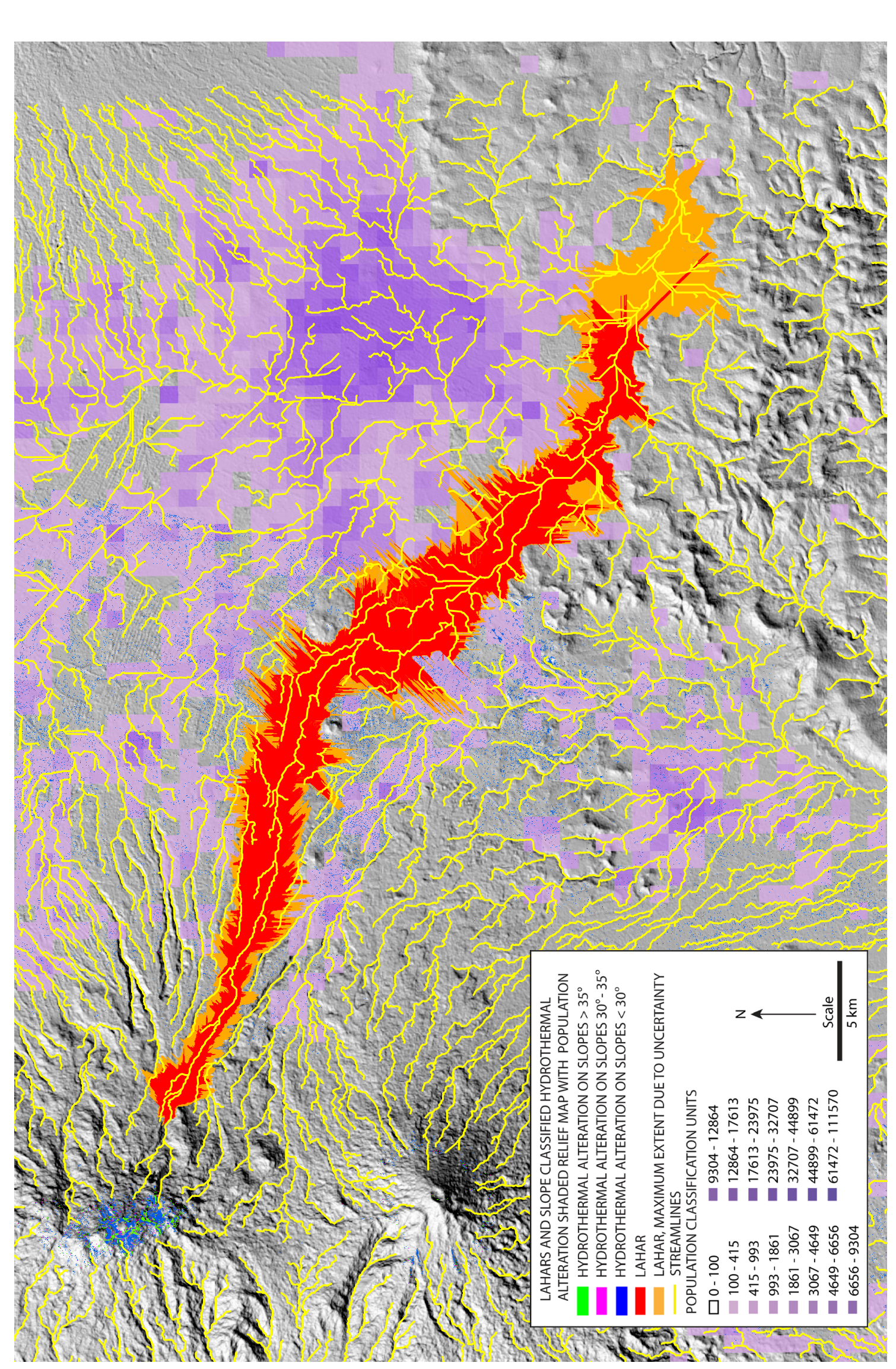

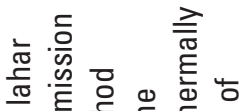

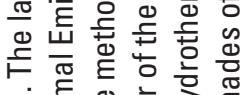
元

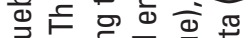

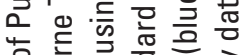

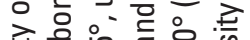
긍ㅇ⿺ㅇ 용 o 0 o क क

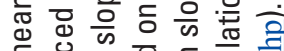

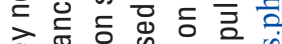
齿

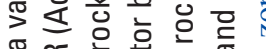

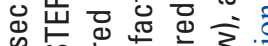

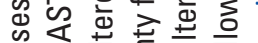
ए 응

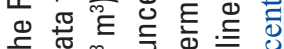
등

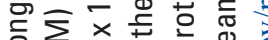
㟧心

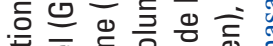
증 흥 言这

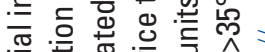

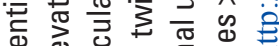

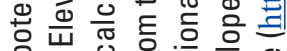

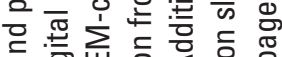

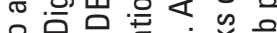
음

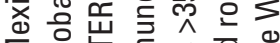

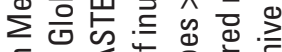

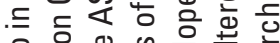

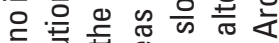

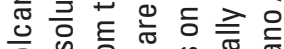

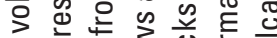
둘

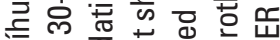
등 E 등

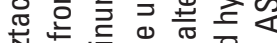
궁 की 家

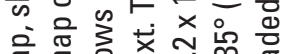

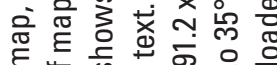

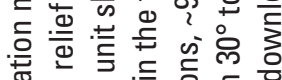

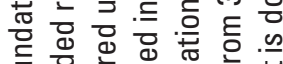

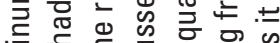
क力

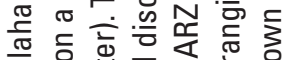

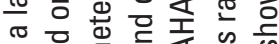

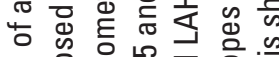
응 은 흥 를 흘 凶ᄄ

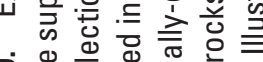
of

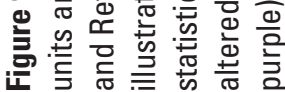




\section{Conclusions}

Hydrothermal alteration mineral maps consisting of argillic and phyllic hydrothermal alteration mineral groups and the mineral jarosite were compiled for 100 volcanoes with nearby populations. ASTER SWIR data were used to compile the hydrothermal alteration maps because the data have sufficient spectral resolution to distinguish SWIR AL-O-H and O-H spectral absorption features for argillic and phyllic mineral groups, and jarosite (fig. 1). When ASTER-derived mineral maps were compared to AVIRIS-derived maps, which have a greater spectral range, the overall patterns of hydrothermally altered rocks were very similar (figs. 1 and 3).

ASTER-mapped hydrothermally altered rock units were classified based on degree of surface slope to characterize potential lahar hazards. Three slope-classified units were selected based on the depositional angles of repose derived from ASTER GDEM data. Surfaces $>35^{\circ}$ were interpreted to consist primarily of exposed hydrothermally altered bedrock, while surfaces with slopes of $35-30^{\circ}$ represent a transition zone from mostly bedrock to talus-covered surfaces, and surfaces with slopes $<30^{\circ}$ were interpreted to consist of mostly talus and were considered to be less prone to collapse.

This is the first study to compile a global database of hydrothermally altered volcanoes showing hydrothermal alteration maps that depict potentially affected drainages, populated areas, and potential inundation maps illustrating modeled lahar inundation zones. Of the 100 volcanoes mapped, 17 exhibit laterally extensive, altered summits and potentially pose a significant threat of generating lahars that could impact populated areas. Some of the volcanoes such as Iztaccíhuatl in Mexico have documented, ancient lahars that covered areas that now have large population centers (Siebe and others, 1996). In addition, the ancient Iztaccíhuatl lahars are similar in size to the Iztaccíhuatl lahar model compiled for this study (fig. 9; Siebe and others, 1996).

For each mapped volcano, geotiff and $\mathrm{kml}$ files are provided for (1) a map illustrating composition and distribution of hydrothermally altered rocks, (2) a map of slope-classified hydrothermally altered rocks, with watersheds and populated areas that may be affected, and (3) a false color composite image indicating bare rock and soil, snow and ice, vegetation, and cloud cover. In addition, hydrothermal alteration and lahar inundation units are available for download as $\operatorname{ArcGIS}^{\circledR}$ shape files and in $\mathrm{kml}$ format for Mount Shasta in northern California, Mount Hood in northern Oregon, and Iztaccíhuatl Volcano in central Mexico. All data can be loaded into popular image and GIS software packages such as ArcGIS ${ }^{\circledR}$, Adobe Photoshop ${ }^{\circledR}$, and Google Earth ${ }^{\mathrm{TM}}$. Data products can be accessed from the ASTER Volcano Archive Web site (http://ava.jpl.nasa.gov/ recent alteration zones.php).

Although these data provide useful information showing hydrothermally altered rocks on steep volcanic slopes and the populated areas downstream that may be affected by potential lahar inundation, they should not be used in place of existing volcano hazard maps published by local authorities. These datasets can also be used to (1) provide additional safety and hazard information related to hydrothermally altered source rocks, (2) delineate stream drainages that may have been inundated in the past by lahars, and allow for field studies of related lahar terrace deposits, and (3) provide additional constraints about noneruptive factors (snow, ice, slope, and hydrothermal alteration) that could be considered in constructing or revising official volcano hazard maps that include zones likely to be inundated by lahars. For international volcanoes without hazard maps and (or) published lahar-related hazard studies, this work will provide a starting point from which more accurate hazard maps can be produced.

\section{Acknowledgments}

Funding for this study was provided by the NASA Applied Sciences Disasters Program, and was carried out, in part, under contract to NASA at the Jet Propulsion Laboratory of the California Institute of Technology. We wish to thank Jim Vallance, Greg Vaughn, and Mike Abrams for reviewing the manuscript.

\section{References}

ASTER GDEM Validation Team, 2009, ASTER global DEM validation summary report: The Land Processes Distributed Active Archive Center, 28 p., https://lpdaac.usgs.gov/sites/ default/files/public/aster/docs/ASTER_GDEM_Validation_Summary_Report.pdf.

Beverage, J. P., and Culbertson, J. K., 1964, Hyperconcentrations of suspended sediment: Journal of the Hydraulics Division, v. 90, no. HY6, p. 117-126.

Bhaduri, B., Bright, E., Coleman, P., Urban, M., 2007, LandScan USA; A high resolution geospatial and temporal modeling approach for population distribution and dynamics: GeoJournal, v. 69, p. 103-117.

Cameron, K.A., and Pringle, P.T., 1986, Post-glacial lahars of the Sandy River basin, Mount Hood, Oregon: Northwest Science, v. 60, no. 4, p. 225-237.

Carrasco-Núñez, G., Díaz-Castellón, R., Siebert, L., Hubbard, B., Sheridan, M.F., Rodríguez, S.R., 2006, Multiple edifice-collapse events in the Eastern Mexican Volcanic Belt; the role of sloping substrate and implications for hazard assessment: Journal of Volcanology and Geothermal Research, v. 158, p. 151-176.

Crandell, D.R., 1971, Postglacial lahars from Mount Rainier volcano, Washington: U.S. Geological Survey Professional Paper 677, 75 p. 
Crandell, D. R., and Waldron, H. H., 1956, A recent volcanic mudflow of exceptional dimensions from Mount Rainier, Washington: American Journal of Science, v. 256, p. 384-397.

Crowley, J. K., and Zimbelman, D. R., 1997, Mapping hydrothermally altered rocks on Mount Rainier, Washington, with Airborne Visible/Infrared Imaging Spectrometer (AVIRIS) data: Geology, v. 25, p. 559-562.

Crowley, J.K., Hubbard, B.E., and Mars, J.C., 2003, Analysis of potential debris flow source areas on Mount Shasta, California, by using airborne and satellite remote sensing data: Remote Sensing of the Environment, v. 87, p. 345-358.

Devoli, G., Cepeda, J., and Kerle, N., 2009, The 1998 Casita volcano flank failure revisited-New insights into geological setting and failure mechanisms: Engineering Geology, v. 105 , p. $65-83$.

Excelis, 2008, The Environment for Visualizing Images (ENVI $\left.{ }^{\circ}\right)$ software: Boulder, Colorado, Excelis Visual Information Solutions, http://www.exelisvis.com/ProductsServices/ENVIProducts/ENVI.aspx.

Finn, C.A., Deszcz-Pan, M., Anderson, E.D., and John, D.A., 2007, Three-dimensional geophysical mapping of rock alteration and water content at Mount Adams, Washington; Implications for lahar hazards: Journal of Geophysical Research, v. 112, B10204, doi:10.1029/2006JB004783, 21 p.

Fujisada, H., 1995, Design and performance of ASTER instrument, in Fujisada, H., and Sweeting, M.N., eds., Advanced and next-generation satellites: Proceedings of International Society Optical Engineering, v. 2583, p. 16-25.

Guthrie, R.H., Friele, P., Allstadt, K., Roberts, N., Evans, S.G., Delaney, K.B., Roche, D., Clague, J.J., and, Jakob, M., 2006, The 6 August 2010 Mount Meager rock slide-debris flow, Coast Mountains, British Columbia; Characteristics, dynamics, and implications for hazard and risk assessment: Natural Hazards and Earth System Science, v. 12, L15305, p. 1277-1294, doi:10.5194/nhess-12-1277-2012.

Hubbard, B.E., 2001, Volcanic hazard mapping using aircraft, satellite, and digital topographic data; Pico de Orizaba (Citlaltépetl), Mexico: Buffalo, N.Y., State University of New York at Buffalo, Ph.D. dissertation, 354 p.

Hubbard, B. E., Sheridan, M. F., Carrasco-Núñez, G., DíazCastellón, R., Rodríguez, S. R., 2007, Comparative lahar hazard mapping at Volcan Citlaltepetl, Mexico using SRTM, ASTER and DTED-1 digital topographic data: Journal of Volcanology and Geothermal Research, v. 160, p. 99-124.

Hunt, G.R., 1977, Spectral signatures of particulate minerals in the visible and near infrared, Geophysics, v. 42, p. 501-513.
Hunt, G.R., and Ashley, R.P., 1979, Spectra of altered rocks in the visible and near infrared: Economic Geology and the Bulletin of the Society of Economic Geologists, v. 74, p. 1613-1629.

ImSpec LLC., 2004, ACORN 5.0 tutorial manual: Pasadena, Calif., ImSpec, LLC, 143 p., http://www.imspec.com.

Iverson, R.M., Schilling, S.P., and Vallance, J.W., 1998, Objective delineation of lahar-inundation hazard zones: Geological Society of America Bulletin, v. 110, p. 972-984, doi: 10.1130/0016-7606(1998).

John, D.A., Sisson, T.W., Breit, G.N., Rey, R.O., and Vallance, J.W., 2008, Characteristics, extent and origin of hydrothermal alteration at Mount Rainier Volcano, Cascades Arc, USA: Implications for debris-flow hazards and mineral deposits: Journal of Volcanology and Geothermal Research, v. 175 , p. 289-314.

John, D.A., Ayuso, R.A., Barton, M.D., Blakely, R.J., Bodnar, R.J., Dilles, J.H., Gray, F., Graybeal, F.T., Mars, J.C., McPhee, D.K., Seal, R.R., Taylor, R.D., and Vikre, P.G., 2010, Porphyry copper deposit model, chapter B of Mineral deposit models for resource assessment: U.S. Geological Survey Scientific Investigations Report 2010-5070-B, 169 p., accessed January 15, 2011, at http://pubs.usgs.gov/ $\operatorname{sir} / 2010 / 5070 / \mathrm{b} /$.

Manville, V., 2004, Paleohydraulic analysis of the 1953 Tangiwai lahar; New Zealand's worst volcanic disaster: Acta Vulcanologica, v. 16, p. 137-152.

Mars, J.C., and Rowan, L.C., 2006, Regional mapping of phyllic- and argillic-altered rocks in the Zagros magmatic arc, Iran, using Advanced Spaceborne Thermal Emission and Reflection Radiometer (ASTER) data and logical operator algorithms: Geosphere, v. 2, p. 161-186, 2 plates.

Mars, J.C., and Rowan, L.C., 2010, Spectral assessment of new ASTER SWIR surface reflectance data products for spectroscopic mapping of rocks and minerals: Remote Sensing of Environment, v 114, p. 2011-2025.

Mars, J.C., 2014, Regional mapping of hydrothermally altered igneous rocks along the Urumieh-Dokhtar, Chagai, and Alborz Belts of western Asia using Advanced Spaceborne Thermal Emission and Reflection Radiometer (ASTER) data and Interactive Data Language (IDL) logical operators-A tool for porphyry copper exploration and assessment: U.S. Geological Survey Scientific Investigations Report 2010-5090-O, 36 p., 10 plates, and spatial data, available at http://dx.doi.org/10.3133/sir20105090O.

Opfergelt, S., Delmelle, P., Boivin, P., Delvaux, B., 2006, The 1998 debris avalanche at Casita volcano, Nicaragua; Investigation of the role of hydrothermal smectite in promoting slope instability: Geophysical Research Letters, v. 33, L15305, p. 59-79, doi:10.1029/2006GL026661. 
Pierson, T.C., and Costa, J.E., 1987, A rheologic classification of subaerial sediment-water flows: Reviews in Engineering Geology, v. 7, p. 1-12.

Reid, M.E., Christian, S.B., and Brien, D.L., 2000, Gravitational stability of three-dimensional stratovolcano edifices: Journal of Geophysical Research, v. 105, no. B3, p. 60436056.

Reid, M.E., Brien, D.L., and Waythomas, C.F., 2006, Preliminary Slope-Stability Analysis of Augustine Volcano, chap. 14 in Power, J.A., Coombs, M.L. and Freymueller, J.T., eds., The 2006 Eruption of Augustine Volcano, Alaska: U.S. Geological Survey Professional Paper 1769, p. 321-332.

Robinson, J.E., Clynne, M.A., 2012, Lahar hazard zones for eruption-generated lahars in the Lassen Volcanic Center, California: U.S. Geological Survey Scientific Investigations Report 2012-5176-C, 13 p.

Rowan, L.C., Hook, S.J., Abrams, M.J., and Mars, J.C., 2003, Mapping hydrothermally altered rocks at Cuprite, Nevada, using the Advanced Spaceborne Thermal Emission and Reflection Radiometer (ASTER), a new satellite-imaging system: Economic Geology and the Bulletin of the Society of Economic Geologists, v. 98, p. 1019-1027.

Rowan, L.C., Schmidt, R.G., and Mars, J.C., 2006, Distribution of hydrothermally altered rocks in the Reko Diq, Pakistan mineralized area based on spectral analysis of ASTER data: Remote Sensing of Environment, v. 104, p. 74-87.

Schilling, S.P., 1998, LAHARZ; GIS programs for automated mapping of lahar-inundation hazard zones: U.S. Geological Survey Open-File Report 98-638, 79 p.

Schilling, S.P., 2014, Laharz_py_-GIS tools for automated mapping of lahar inundation hazard zones: U.S. Geological Survey Open-File Report 2014-1073, 78 p., http://dx.doi. org/10.3133/ofr20141073. ISSN 2331-1258 (online)

Scott, K.M., Vallance, J.W., and Pringle, P.T., 1995, Sedimentology, behavior, and hazards of debris flows at Mount Rainier, Washington: U.S. Geological Survey Professional Paper 1547, 56 p.

Scott, K. M., Vallance, J. W., Kerle, N., Macias, J. L., Strauch, W., and Devoli, G., 2005, Catastrophic, precipitation-triggered lahar at Casita volcano, Nicaragua-Flow transformations, flow bulking, and future mitigation strategies: Earth Surface Processes and Landforms, v. 30, 59-79.

Siebe, C., Abrams, M., Macias, J.L., and Obenholzner, J., 1996, Repeated volcanic disasters in Prehispanic time at Popocatepetl, central Mexico; Past key to the future?: Geology, v. 24, p. 399-402.

Tucker, C.J., Grant, D.M., and Dykstra, J.D., 2004, NASA's global orthorectified Landsat dataset: Photogrammetric Engineering and Remote Sensing, v. 70, p. 313-322.
Vallance, J.W., and Scott, K. M., 1997, The Osceola mudflow from Mount Rainier; Sedimentology and hazards implications of a huge clay-rich debris flow: Geological Society of America Bulletin, v. 109, p. 143-163.

Vallance, J.W., 1999, Postglacial lahars and potential hazards in the White Salmon River system on the southwest flank of Mount Adams, Washington: U.S. Geological Survey Bulletin $2161,49 \mathrm{p}$.

Vallance, J.W., 2000, Lahars in Sigurdsson, H., ed., Encyclopedia of Volcanoes: San Diego, Calif., Academic Press, p. 601-616.

Vallance, J.W., 2005, Volcanic debris flows in Jakob, M. and Hungr, O. eds., Debris-flow Hazards and Related Phenomena: Praxis, Springer Berlin Heidelberge, p. 247-274.

Vallance, J. W., Schilling, S.P., Devoli, G., Reid, M.E., Howell, M.M., and Brien, D.L., 2004, Lahar hazards at Casita and San Cristobal volcanoes, Nicaragua: U.S. Geological Survey Open-File Report 01-468, 24 pp.

Van Wyk de Vries, B., and Francis, P.W., 1997, Catastrophic collapse at stratovolcanoes induced by gradual volcanic spreading: Nature, v. 387, p. 387-390.

Van Wyk de Vries B., Kerle N., Petley D., 2000, Sector collapse forming at Casita volcano, Nicaragua: Geology, v. 28, p. $167-170$.

Voight, B., and Elsworth, D., 1997, Failure of volcano slopes: Geotechnique, v. 47, no. 1, p. 1-31.

Watters, R.J., Zimbelman, D.R., Bowman, S.D., and Crowley, J.K., 2000, Rock mass strength assessment and significance to edifice stability, Mount Rainier and Mount Hood, Cascade Range volcanoes: Pure and Applied Geophysics, v. 157, p. 957-976.

Zimbelman, D. R., 1996, Hydrothermal alteration and its influence on volcanic hazards-Mount Rainier, Washington, a case history:Boulder, University of Colorado, Ph.D. thesis, $384 \mathrm{p}$.

Zimbelman, D. R., Rey, R.O., and Breit, G.N., 2005, Origin of secondary sulfate minerals on active andesitic stratovolcanoes: Chemical Geology, v. 215, p. 37-60.

\author{
Menlo Park Publishing Service Center, California \\ Manuscript approved for publication February 25, 2015 \\ Edited by Claire M. Landowski \\ Design and layout by Vivian Nguyen
}




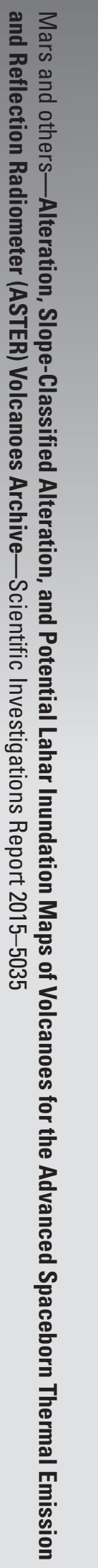

